\title{
ARTICLES
}

\section{IMMIGRANT CRIMINALS IN OVERCROWDED PRISONS: RETHINKING AN ANACHRONISTIC POLICY}

\author{
Peter H. SCHUCK*
}

\section{INTRODUCTION}

Immigrants $^{1}$ are less likely than American citizens to be convicted of crimes committed in the United States. ${ }^{2}$ Nevertheless, the total immigrant population, including both those with documented and undocumented status, ${ }^{3}$ is now so large that the number of immigrants in American prisons and jails is very significant. At the same time, many state prisons and local jail

* Simeon E. Baldwin Professor Emeritus of Law, Yale Law School. Many thanks for outstanding research assistance from three highly talented Yale Law School students, Talia Kraemer, class of 2012, Katherine Reisner, class of 2011, and Jacob Goldberg, class of 2015. Ms. Kraemer prepared appendices 1, 2, 4 and 6-8 to this Article, Ms. Reisner prepared appendices 3 and 5, and Mr. Goldberg prepared appendix 9 . Mr. Goldberg updated the manuscript at the end of its long gestation period. Useful comments were contributed by Professors Rachel Barkow, Jonathan Caulkins, James Jacobs, Stephen Legomsky, Ron Levin, David Martin, Alan Morrison, and David Shapiro; by Gary Mead; by participants in a University of California at Irvine Law School symposium, "Immigration Puzzles," and in faculty workshops at the law schools of the University of California at Los Angeles, Washington University at St. Louis, Fordham University, New York University, Brooklyn, and the University of Texas at Austin. (C) 2014, Peter H. Schuck.

1. In this paper, I use the term "immigrants" to include both legal and undocumented non-citizens unless the context requires distinguishing between these two categories. The Immigration and Nationality Act uses the term "alien" to refer to all non-citizens, but in deference to sensibilities about that off-putting term, 1 follow Professor Stephen Legomsky in minimizing the use of it. STIEPHEN H. Liziomsky \& Cristina M. Rodriguiż, Immigiration And Refuglie Law And Policy 1 (5th ed. 2009).

2. E.g., ACLU Immigrant Rights Project, Issue Brief: Criminalizing Undoocumentid ImmiGRANTS 4 (February 2010), available at https://www.aclu.org/files/assets/FINAL_criminalizing undocumented_immigrants_issue_brief_PUBLIC_VERSION.pdf.

3. As of February, 2011, the total foreign-born population in the United States on January 1, 2010 was estimated to be $31,950,000$, including approximately 10,795,000 unauthorized foreign-born residents. DHS OFFICE OF IMMIGRATION STATISTICS, Estimatis OF THE UNAUTHORIZIED IMMIGRANT Population Residing in the United States: January 2010, at 3, tbl. 2 (2011). An estimated 13.3 million legal permanent residents lived in the U.S. on January 1, 2012. DHS OFFICE OF Immigration Statistics, Estimatis Of The Legal. Permanent Risident Population in 2012 (2013), available at http://www.dhs.gov/sites/default/files/publications/ois_lpr_pe_2012.pdf. 
systems have experienced overcrowding so severe that the United States. Supreme Court, some lower federal courts, and many state courts have found the resulting conditions of incarceration unconstitutional. ${ }^{4}$ These judges have sought to remedy the overcrowding by ordering that prison populations be reduced by thousands of inmates-approximately 40,000 in California alone. ${ }^{5}$ As we shall see, California is not even close to meeting this target, and presumably the same is true of other states under court order.

This response to prison over-crowding is not confined to judges. State officials, responding to budgetary pressures and concerns about safety and rehabilitation conditions in the prisons, have attempted to reduce their prison populations administratively, principally through transfers to out-of-state facilities, community diversion programs, and early release programs, usually involving expanded parole. Indeed, most early releases today are driven less by court orders than by severe fiscal pressures on federal, state, and local officials. $^{6}$

This Article proposes the early release and removal of many deportable immigrant criminals. ${ }^{7}$ The term early release here does not refer to programs that divert convicted criminals to drug treatment and other community services in lieu of incarceration. ${ }^{8}$ Nor am I referring to the parole of

4. Brown v. Plata, 131 S. Ct. 1910 (2011). See also, e.g., Tillery v. Owens, 907 F.2d 418, 421 (3d Cir. 1990) (finding that the practice of "double-celling" violated the Eighth Amendment); Wellman $v$. Faulkner, 715 F.2d 269 (7th Cir. 1983) (finding a prison "unconstitutionally overcrowded"). See generally WAYNE N. WELSH, COUNTIES IN COURT. JAIL OVERCROWDING AND COURT-ORDERED REFORM 4 (1995) (comprehensive study of prison condition litigation finding that "[i]n 1993, forty states had at least one state prison under a court order or consent decree to limit population or improve general conditions of confinement; eleven of these states were operating their entire judicial system under judicial decree"). Litigation regarding abysmal prison conditions caused primarily by overcrowding became so frequent that in 1996 Congress passed the Prison Litigation Reform Act ("PLRA") in an effort "to address the alarming explosion in the number of frivolous lawsuits filed by State and Federal prisoners." 141 CONG. REC. S14, 413 (daily ed. Sept. 27, 1995) (statement of Sen. Dole, introducing the PLRA in the Senate), cited in Susanna Y. Chung, Prison Overcrowding: Standards in Determining Eighth Amendment Violations, 68 FordHAM L. REv. 2351, 2365 (2000). Some jurisdictions, such as New York City, have experienced a decline in their jail populations. See Sam Roberts, As Crime Rate Drops, New York's Jail Population Falls to Lowest Level in 24 Years, N.Y. Times, June 10, 2010, http://www.nytimes.com/2010/06/11/nyregion/11jails.html (also noting that in many other cities with decreasing crime rates, jail population has not declined).

5. Plata, $131 \mathrm{~S}$. Ct. at 1923. See discussion infra notes 83-96 and accompanying text.

6. The volume of court-ordered early releases of criminals due to prison over-crowding has declined since Congress enacted the PLRA, which restricts courts' power to issue such releases. See supra note 3. For an analysis of the PLRA's effect on such releases, see Margo Schlanger, Civil Rights Injunctions over Time: A Case Study of Jail and Prison Court Orders, 81 N.Y.U. L. REv. 550, 589 (2006).

7. In this article, I shall use the terms "deportation" and "removal" interchangeably.

8. On diversion programs, see, e.g., S. Christopher Baird \& Dennis Wagner, Measuring Diversion: The Florida Community Control Program, 36 CRIME \& DelinquenCY 112 (1990); Elizabeth Piper Deschenes, Susan Turner \& Joan Petersilia, A Dual Experiment in Intensive Community Supervision: Minnesota's Prison Diversion and Enhanced Supervised Release Programs, 75 PRISON J. 330 (1995); Henry J. Steadman \& Michelle Naples, Assessing the Effectiveness of Jail Diversion Programs for Persons with Serious Mental Illness and Co-Occurring Substance Use Disorders, 23 Behav. Sci. Law 163 (2005); see also Nat'l Ass'n of Pretrial Servs. Agencies, Pretrial Diversion in the 21 st Century: A National Survey of Pretrial Diversion Programs and PraCtices (2009) (surveying pretrial diversion programs around the country). On drug courts, see, 
incarcerated criminals before they have completed their maximum sentences, usually if they demonstrate good behavior, pose low recidivism risks, and are thought likely to comply with parole conditions, where parole is permitted. ${ }^{9}$ Early release of immigrant criminals here refers to a quite different practice: the deportation of sentenced prisoners before the time when they might otherwise complete their sentences or qualify for good behavior parole, solely because of illegal over-crowding. ${ }^{10}$

Early releases of any kind may serve important correctional and other social goals, including lower incarceration costs, more manageable programming within prisons, improving the living and working conditions of prisoners, guards and administrators, motivating and rewarding good behavior by inmates and ameliorating some of the adverse effects of sentencing practices that are widely, but not uncontroversially, considered too harsh. ${ }^{11}$

Early releases in order to alleviate overcrowding, however, can also threaten public safety, confidence, and tranquility. First, early releases increase the already-significant risks that those who are freed will violate

e.g., Editorial, Stay out of jail clean, THE ECONOMIST, Jan. 26, 2011, at 38. These programs are gaining bipartisan support. See, e.g., id.; Newt Gingrich \& Pat Nolan, Op-Ed., Prison Reform: $A$ Smart Way for States to Save Money and Lives, WASH. PoST, Jan. 7, 2011, http://www. washingtonpost. $\mathrm{com} / \mathrm{wp}$-dyn/content/article/2011/01/06/AR2011010604386.html. Some diversion and alternative-toincarceration programs deny eligibility to non-U.S. citizens. See Immigrants Behind Bars: How, Why, and How Much?, NAT'L IMMIGRATION FORUM (March 2011), http://www.immigrationforum.org/images/ uploads/2011/immigrants_in_local_jails.pdf; N.Y.C. Bar Ass'n, Immigration Detainers Need Not Bar Access to Jail Diversion Programs (2009) (identifying obstacles to non-U.S.-citizen participation in certain New York diversion programs and arguing for strategies to facilitate such participation).

9. Since the 1980s, the federal government and some states (not California or New York) have eliminated or severely limited early release through parole. See ISAAC Fulwood, U.S. DEP'T of Justice, History of THE Federal. PARole System (2003), available at http://www.justice.gov/uspc/ history.pdf; Jeremy Travis \& Sarah Lawrence, Urban Inst. Justice Policy CTr., Beyond the Prison Gates: The State of PAROLe in AmERica 1 (2002) (surveying state parole practices); Ilyana Kuziemko, Going Off Parole: How the Elimination of Discretionary Prison Release Affects the Social Cost of Crime 5-7 (Nat'l Bureau of Econ. Research, Working Paper No. 13380, 2007) (discussing the history of state parole practices).

10. ICE's Rapid REPAT program, discussed in further detail infra Appendix 3, allows for certain incarcerated immigrants to be released from state prisons before they have completed their sentences or qualified for good-behavior parole. However, Rapid REPAT is limited to immigrants convicted of non-violent crimes, and states must enact legislation meeting enumerated conditions in order to join the program.

11. See, e.g., Jeffrey Fagan \& Tracey L. Meares, Punishment, Deterrence and Social Control: The Paradox of Punishment in Minority Communities, 6 OHIO ST. J. CRIM. LAW 173 (2008) (arguing that increasingly harsh punishment (1) erodes families and the economic well-being of already poor communities, thereby weakening informal social controls that reduce crime, and (2) diminishes respect for the legitimacy of punishment, further causing a counter-deterrent effect); VALERIE Wright, Sentencing Project, Deterrence in Criminal Justice, Evaluating Certainty vs. SeverITY OF PUNISHMENT 6-7 (2010) (summarizing studies showing that offenders who serve longer sentences have slightly higher recidivism rates, and arguing that lower-risk offenders are most negatively affected by longer sentences, because longer prison terms cause the offenders to lose community ties and become further removed from legitimate opportunities in society). For a specific example, see U.S. v. Polouizzi, 760 F. Supp. 2d 284 (E.D.N.Y. Jan. 14, 2011) (rejecting imprisonment under the Sentencing Guidelines for receipt and possession of child pornography as "grossly excessive"). 
parole conditions and commit additional crimes, ${ }^{12}$ sometimes very serious crimes. ${ }^{13}$ Second, they stoke the community's fear of crime and threaten its sense of public order; these effects, although important in themselves, can also have serious political repercussions. ${ }^{14}$ Third, early releases may weaken the deterrent and retributive effects of the criminal sanctions already on the books and according to which the released prisoners were convicted and sentenced. ${ }^{15}$ For these reasons, minimizing the necessity for early releases that are designed purely to alleviate overcrowding, rather than to serve the

12. The most recent federally-funded data indicate that recidivism rates in the United States are

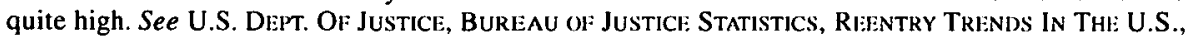
available at http://bjs.ojp.usdoj.gov/content/reentry/recidivism.cfm (last updated January 22, 2014) (a 15-state study found that 67.5 percent of prisoners released in 1994 in the states surveyed in the study were rearrested, and 46.9 percent of prisoners released were reconvicted within 3 years). A 1995 study found that among federal offenders, the recidivism rate was lower among non-citizens (17.1 percent of prisoners reoffended within two years of release) than among citizens ( 22.8 percent of prisoners reoffended within two years of release). Michael Edmund O'Neill, Linda Drazga Maxfield, \& Miles D. Harer, Past As Prologue: Reconciling Recidivism and Culpability, 73 Fordun L. REv. 245, 276 (2004). O'Neill, et. al., assert that "The lower noncitizen recidivism rate is expected because noncitizens are usually deported to their native countries after completing their criminal sentences. When criminal offenses occur outside of the United States, subsequent offenses cannot be recorded .... What is unexpected is that nearly $20 \%$ of noncitizen offenders were back in the U.S. recidivating within the two year recidivism follow-up period." Id. Some states have experienced increased recidivism rates in the past decade. MARShal, Clemlint, MATthew Schwarzhil,d, \& Michael Thompson, Council of State Governments Justicle Center, Thi National. Summit on Justice Reinvestment and Public Safety: Addrissing Ri:Cidivism, Crimi, and Corri:ctions SPENDING 3 (2011).

13. A new California statute providing for the early release of prisoners went awry shortly after enactment when several hundred inmates at county jails were incorrectly released and soon committed crimes. Recidivism by those released is common. See, e.g., Plata, $131 \mathrm{~S}$. Ct. at 1965-66 (Alito, J., dissenting) (describing Philadelphia's "spectacularly unsuccessful" release experience); Randall C. Archibold, California, in Financial Crisis, Opens Prison Doors, N.Y. Times, Mar. 23, 2010, at A14. Much the same occurred in the recent early release program in Illinois. The state Department of Corrections had failed to keep violent criminals out of the revised program, which released about 1,745 individuais. Dozens of parolees released through the program, including some convicted violent criminals, disappeared after they were set free. Some absconders were picked up again quickly, but others remained at large for many months. John O'Connor, IIl. Purolees Disappear After Being Released Early, Associatis PREss, June 23, 2010. The Associated Press later found that more than 1,000 of the revised "meritorious good time" parolees, or 58 percent, had gone back to prison after being accused of new crimes or other parole violations. Some violations appear minor, but others involved allegations of violent crimes. John O'Connor, III. Parolee Wasn't Picked Up After Battery Claim, Associated Press, Sep. 20, 2010.

14. For example, in the Illinois case described supra note 13, a gubernatorial election was taking place at the time the scandal made news. Prior to the breaking of the news of the early releases, incumbent governor Pat Quinn had been leading in the gubernatorial election by a margin of two-to-one over his opponent, Hynes. After Hynes attacked him about the failed program, however, and aired attack ads that stoked public fear about criminals on the loose, the race fell to a near dead heat, although Quinn did go on to win the election. Rick Pearson, Poll Shows Close Races in Illinois Primaries, L.A. TIMEs, Jan. 24, 2010, ("Hynes has attacked Quinn in TV ads for releasing inmates within days after their arrival at state prisons to save money. Dozens of those released early are back in prison.").

15. I say "perhaps" because criminologists are divided on the strength, or even the existence, of the deterrence effect of the risk of incarceration on potential criminals. See, e.g., MARK A. R. Kleiman, When Brute Force Falls, (2010) (arguing that incarcerating more people for lengthier terms has not been effective in reducing crime, and that what is needed instead is "focused zero tolerance"-concentrating enforcement and punishment); James Q. Wilson, Criminal Justice, in Understanding america: The anatomy of an Excizpional. Nation 475 (Peter H. Schuck \& James Q. Wilson eds., 2008). 
salutary goals described above, is an important policy objective.

In this article, I analyze the relationship between (1) the incarceration of large numbers of deportable criminal immigrants ${ }^{16}$ - those whom the Immigration and Customs Enforcement (ICE) agency ${ }^{17}$ could legally remove ${ }^{18}$ from the United States under the immigration statute because of their criminal convictions or other reasons; ${ }^{19}$ and (2) the severe legal, budgetary, and political pressures on the federal and many state prison systems to reduce over-crowding through early releases of prisoners, whether deportable or not.

In this article I argue that the problem of prison overcrowding in the United States-a problem often of constitutional dimensions-can be alleviated $^{20}$ by removing deportable criminal immigrants before they are imprisoned here, or if they are imprisoned here, as soon as their removal becomes feasible, and arranging for them to serve the remainder of their sentences instead in the country to which they are removed. ${ }^{21}$ In addition to the other important advantages of early deportations discussed below, such a policy should reduce the need for early releases of criminals, both citizens and immigrants, whose recidivism risks are sufficiently high that officials would oppose releasing them. ${ }^{22}$ Two major legal obstacles, however, impede implementation of an early deportation policy. ${ }^{23}$ The first is an almost century-old statute, what I call the "imprisonment-before-deportation rule," which generally prohibits the government from deporting criminal immigrants until they have served their full sentences in the United States. ${ }^{24}$ The second is a system of prisoner transfer treaties (PTTs), legal arrangements that permit countries to remove foreign-national prisoners ${ }^{25}$ to their countries

16. The label "criminal alien" is a statutory term referring to an alien who has committed a crime that may render him removable. Nevertheless, for the reason given supra note 1, I shall instead use the term "criminal immigrant" whenever possible.

17. ICE, an agency within the Department of Homeland Security (DHS), carries out deportations.

18. In this paper, 1 use the terms "deportation" and "removal" (and their variants) interchangeably, but mostly use deportation, which is the more familiar and colloquial of the two. Congress in 1996 substituted the term "removal" in most situations. Illegal Immigration Reform and Immigrant Responsibility Act of 1996, Pub. L. No. 104-208, div. C, \$ 306(a), 110 Stat. 3009, (1996).

19. For the law governing crime-based removals, see Immigration and Nationality Act, Sec. 237(a)(2), 8 U.S.C. \$1227(a)(2) (2006); Charl.les Gordon, Stani.ey Mailman, \& Stephen YaleLOEHR, IMMIGRATION LAW AND PROCEDURE $\$ 71.05$.

20. I say "alleviated," not "eliminated" because the overcrowding is so severe in many states that other measures, which are discussed briefly below, will also be required.

21. As noted in Part V, the probability that they would in fact serve the remainder of their sentences abroad would and should be a very important factor in deciding whether to deport them early, but would not necessarily control that decision, if other factors weighed more heavily.

22. In principle and in practice, both approaches could be used simultaneously. Thus, to the extent that pre-imprisonment deportation of criminal immigrants reduced the prison population, less or no (depending on the numbers) judicial intervention to reduce overcrowding would be necessary.

23. I discuss some non-legal obstacles in Part IV.

24. INA Sec. 241 (a)(4)(A). Two exceptions are provided in Sec. 24l(a)(4)(B).

25. Dual citizenship does not disqualify applicants: under most PTTs and under the U.S. PTT regime, a prisoner need only be a citizen or national of the country to which he wants to be transferred. He may be a citizen or national of the country in which he is imprisoned and still apply for transfer. In the United States however, his dual citizenship may become a factor in the approval of his application, given that one of the factors considered in the approval process is the likelihood of the 
of nationality to serve out the remainder of their sentences. The United States currently has bilateral prisoner transfer treaties in force with twelve countries ${ }^{26}$ and is also a party to two multilateral PTTs. ${ }^{27}$ PTTs are the subject of Part IV.C.

In at least one way, widely-supported immigration policy reforms are making the overcrowding problem worse. Recognizing their need for better information and coordination with criminal law enforcement agencies at the state and local levels, federal immigration officials have launched several much-heralded policy initiatives. The policies-particularly the Criminal Alien Program (CAP) (until recently, known as the Institutional Removal Program (IRP)), and Secure Communities-seek to enable these front-line law enforcement agencies to better identify immigrant arrestees who have criminal records or are in illegal status, and to enable ICE to complete deportation proceedings before immigrant inmates complete their sentences and are released into American society. These programs, which are described in greater detail in Part III, facilitate the identification and custody of deportable immigrant criminals; but they do not alter the imprisonment-beforedeportation rule or the PTTs, and thus, do not ameliorate the prison over-

prisoner's return, and the stronger a prisoner's ties to the country of his imprisonment, the stronger the likelihood is that he will return. See Guidelines for Evaluating Transfer Applications, U.S. DEPT. OF JuSTICE, http://www.justice.gov/criminal/oeo/iptu/guidelines.html. The location of the prisoner's family, his residence and domiciliary status in the United States and the receiving country (for example, does he still own a residence in the United States, does he have any obvious residence in the receiving country), whether he had a non-criminal occupation or professional career in the sending or receiving country, the relative proximity of the receiving country's borders to the United States and how easy or difficult it would be as a practical matter to return to the United States, and his immigration status, are all factors to take into account in determining whether the prisoner would likely remain in the receiving country.") Anyone with American citizenship or nationality may apply for transfer back to the United States. U.S. courts have upheld the ability of U.S. dual citizens to seek prisoner transfer to or from the United States, but have held that the prisoner transfer treaties do not establish a private right of action. The Attorney General's decision to approve or deny applications from prisoners abroad, even if they are dual citizens of the United States, is not subject to review. See e.g., Richey v. Riveland, 26 F.3d 132 (9th Cir. 1994); Coleman v. Reno, 91 F. Supp. 2d 130 (D.D.C. 2000).

26. The countries are Bolivia, Canada, France, Hong Kong S.A.R., Marshall Islands, Mexico, Micronesia, Palau, Panama, Peru, Thailand and Turkey. Prisoner Transfer Treaties, Travel.State. Gov, http://travel.state.gov/law/legal/treaty/treaty_1989.html (last visited Nov. 1, 2011).

27. The first multilateral PTT, the Council of Europe Convention on the Transfer of Sentenced Persons, is in force in Albania, Andorra, Armenia, Australia, Austria, Azerbaijan, Bahamas, Belgium, Bosnia and Herzegovina, Bolivia, Bulgaria, Canada, Chile, Costa Rica, Croatia, Cyprus, Czech Republic, Denmark, Ecuador, Estonia, Finland, France, Georgia, Germany, Greece, Hungary, Iceland, Ireland, Israel, Italy, Japan, Republic of Korea, Latvia, Liechtenstein, Lithuania, Luxembourg, Macedonia (Former Yugoslav Republic of), Malta, Mauritius, Mexico, Moldova, Montenegro, the Netherlands (including Netherlands Antilles and Aruba), Nicaragua, Norway (including Bouvet Island, Peter I's Island and Queen Maud Land), Panama, Poland, Portugal, Romania, Russia, San Marino, Serbia, Slovakia, Slovenia, Spain, Sweden, Switzerland, Tonga, Trinidad and Tobago, Turkey, Ukraine, the United Kingdom (including Anguilla, British Indian Ocean Territory, British Virgin Islands, Cayman Islands, Ducie and Oena Islands, Falkland Islands, Gibraltar, Henderson, Isle Of Man, Montserrat, Pitcairn, St. Helena and Dependencies and the Sovereign Base Areas of Akrotiri and Dhekelia on the Island of Cyprus), and Venezuela. The second multilateral PTT, the InterAmerican Convention on Serving Criminal Sentences Abroad, is in force in Belize, Brazil, Canada, Chile, Costa Rica, Ecuador, El Salvador, Guatemala, Mexico, Nicaragua, Panama, Paraguay, and Venezuela. Id. 
crowding and premature release of immigrant criminals. In fact, these enhanced enforcement programs actually exacerbate the problem by increasing the flow of immigrant criminals into the federal and state prison systems.

The article has five parts. Part I details the problem of large-scale immigrant criminal incarceration and the case for considering a new approach. Part I has four sections. The first section presents data on the trends in convictions and incarceration of immigrants for crimes they committed in the United States. The second section discusses the growing phenomenon of prison overcrowding and the judicial (and in some cases, legislative and executive) responses to this problem; especially court orders requiring or leading to the premature release of many immigrant criminals into the community. The third section describes the official responses to prison overcrowding. The fourth details the situation in California, where prison overcrowding has led to both judicial and administrative requirements for early release, which have recently been affirmed by the United States Supreme Court.

Part II raises and answers a question that seems not to have been asked in the scholarly literature or in Congress, at least since the prison overcrowding problem has become legally, indeed constitutionally, acute: In view of the strong and growing pressures on governments to reduce this chronic and illegal prison overcrowding, why not remove these deportable immigrant criminals, who presumably will be removed eventually, at the earliest opportunity - that is, as soon as is practicable once their criminal convictions and removal orders become final ${ }^{28}$ Why does the law insist that these immigrant criminals serve their full sentences in U.S. prisons at a very high cost to American taxpayers, when much earlier removal could minimize these costs and serve other social and humanitarian goals as well-including, in some cases, the desires of the prisoners themselves for early removal?

The answer turns out to be complicated. One part of the answer, the subject of Part II, is the long-standing imprisonment-before-deportation rule, codified in Section 241(a)(4) of the Immigration and Nationality Act. Enacted in 1917, this provision requires immigrant criminals to serve their sentences in American prisons rather than serving their sentences in their home countries or elsewhere outside the United States. Since its enactment, Congress has

28. Even after direct court appeals of immigrant criminals' convictions and sentencing and of their final removal orders are exhausted, subsequent events in their countries of origin may possibly give them new avenues of relief from removal, such as non-refoulement claims under asylum law, Immigration and Nationality Act Sec. 208, 8 U.S.C. $\$ 1158$ (2006), and the Convention Against Torture, Convention against Torture and Other Cruel, Inhuman or Degrading Treatment or Punishment, Dec. 10, 1984, 1465 U.N.T.S. 85; and claims for discretionary relief that may arise because of marriage to, or parenting of, U.S. citizens. My use of the term "final" should be understood in the narrower, more conventional sense, but without prejudice to these other possibilities. Once returned to their countries of origin, they could pursue any collateral challenges to the underlying conviction and removal that are available to them, albeit from abroad. But see, Jess Bravin, Judge Suggests U.S. Misled Court on Immigration Policy, WALL ST. J., Feb. 10, 2012, at A6 (government may have misled Supreme Court about its policy to help wrongfully deported immigrants return to the U.S.). 
revisited the imprisonment-before-deportation rule only twice: a lone, unsuccessful effort in 1993 by then-Representative Charles Schumer to change this rule, and a 1996 provision that authorized some exceptions for certain non-violent criminals, but that has seldom been used. ${ }^{29}$ Another part of the answer, the subject of Part IV.C., is the system of prisoner transfer treaties (PTTs) which severely limit the circumstances in which the United States and the putative receiving country will effectuate an early deportation; especially one that assures the prisoner will actually serve the rest of his sentence in the receiving country. In light of the prison overcrowding crisis and as a partial remedy for it, this Article proposes that both the statute and the treaties be changed.

Part III turns to the changing political and policy contexts in the decades, beginning in the 1980s, when Congress increasingly adopted a hard line on immigrant crime and insisted that the offenders be swiftly and unceremoniously deported-but again, not until after they have served their sentences in American prisons. ${ }^{30}$ During this period Congress expanded the category of crimes triggering deportation, deprived offenders of most legal defenses to deportation, and sharply limited the availability of equitable, discretionary relief from deportation. Congress adopted these limited exceptions to the imprisonment-before-deportation rule in 1996, but as Part III explains, they have produced remarkably few early removals.

Part IV examines the six main constraints on a policy change to authorize early deportation of immigrant criminals. These constraints include: (A) fear that early deportation would hasten the criminal's illegal re-entry into the United States, and in some cases, nourish the transnational drug and other crime activities that have plagued both the United States and the sending countries, especially Mexico; ${ }^{31}$ (B) concerns that it would reduce deterrence of crimes by immigrants; (C) the PTTs, which should facilitate early deportations, but instead perversely limit them; (D) the community ties that long-term resident immigrant criminals may have here; (E) competition for limited enforcement resources; and (F) political factors.

Considering these constraints, Part V proposes a two-pronged reform. First, Congress should replace Section 241(a)(4) with a provision allowing the appropriate federal officials, after fact-finding according to specified criteria and pursuant to a limited administrative process, to deport removable immigrant criminals as soon as feasible once a final removal order is in place

29. A handful of states have invoked this exception under programs that are discussed infra at note 35 .

30. See generally, Peter H. Schuck \& John Williams, Removing Criminal Aliens: The Pitfalls and Promises of Federalism, 22 Harv. J. L. \& Pub. Policy 367 (2000).

31. See, e.g., Celinda Franco, Cong. Ris. Sizv., Thi MS-13 and 18Th Striet Gancis: Emerging Transnational Gang Threats? (2010) (citing evidence that some deported immigrant gang members have established a "revolving door' migratory pattern of repeat illegal re-entry into the United States" engendering concern about increased criminal activity, including drug trafficking, along the U.S.-Mexico border). 
and direct appeals have been exhausted. This new process would occur after the previously-conducted deportation proceeding leading to the criminal's final deportation order was completed, although it could easily be consolidated with it. Second, the PTTs, especially the one with Mexico, should be renegotiated. The federal government should use financial and diplomatic resources to make repatriation followed by incarceration abroad easier for the United States and more acceptable to the countries to which the criminal immigrants will be removed. The proposed reforms require legislative, diplomatic, and administrative actions.

The main body of this article is followed by nine appendices which present historical background and first-cut, obviously incomplete, policy analyses that seek to identify (and to a limited extent, quantify) the possible advantages and disadvantages of these changes. The analyses estimate the size of the incarcerated immigrant criminal population (Appendix 1); the estimated number of these immigrant criminals who are deportable (Appendix 2); the history of how the statutory exceptions to the imprisonment-beforedeportation rule have been used and not used (Appendix 3); the conviction offenses for immigrants with reinstated orders of removal in FY 2010 (Appendix 4); the implementation of the PTT regime (Appendix 5); the current costs of incarcerating immigrant criminals in American prisons (Appendix 6); various methods for classifying drug offenses according to a "seriousness of crime" criterion (Appendix 7); the fate of past efforts to build and operate federally or state-funded prisons abroad for the incarceration of deported immigrant criminals (Appendix 8); and the policies of Canada and the United Kingdom with respect to the early removal of deportable criminals (Appendix 9).

These preliminary analyses suggest that the proposed reforms could generate substantial benefits of many kinds. Only the federal government can gather the additional information and conduct the necessary analyses needed to support, flesh out, and implement these reforms. At the same time, the government must pursue other kinds of measures to reduce prison overcrowding, many of which would not be specific to immigrant criminals. One benefit of the current fiscal crisis at all levels of government may be that it renders such reform efforts politically attractive and realistic rather than toxic and unattainable.

Before proceeding, it is worth noting a trend among immigration scholars to criticize what they characterize as the increasing criminalization of immigration law. ${ }^{32}$ They will likely oppose the policy changes proposed

32. See, e.g., Nora V. Demleitner, Immigration Threats and Rewards: Effective Law Enforcement Tools in the "War" on Terrorism, 51 EMORY L.J. 1059, 1059 (2002) (describing the use of immigration law as a law enforcement tool in the "war" on terrorism); Daniel Kanstroom, Criminalizing the Undocumented: Ironic Boundaries of the Post-September IIth "Pale of Law," 29 N.C. J. INT'L. L. \& COM. REG. 639,640 (2004) (concluding that the convergence of the criminal justice system and the immigration control system produces the worst features of both models); Daniel Kanstroom, 
here. ${ }^{33}$ These scholars generally oppose, among other policies, the expanded range of crimes that render immigrants excludable and deportable; tighter restrictions on re-entry and other consequences that may flow from immigrants who commit crimes and are deported as a result; the narrowing of the exceptions and other discretionary relief that deportable immigrant criminals might otherwise invoke in order to remain in the country; the prison-like detention practices to which many non-criminal immigrants, especially asylum claimants, are subjected pending their hearings and deportations; and the failure to establish and fund alternative, community-based alternatives to prison for less serious immigrant (and citizen) offenders. ${ }^{34}$ Some of these

Deportation, Social Control, and Punishment: Some Thoughts about Why Hard Cases Make Bad Laws, 113 HARV. L. REv. 1889, 1893-94 (2000) (arguing that deportation of legal permanent residents should be seen as punishment, and, therefore, substantive constitutional protections should apply to deportation proceedings); Maria Isabel Medina, The Criminalization of Immigration Law: Employer Sanctions and Marriage Fraud, 5 GEo. MASON L. REv. 669, 673 (1997) (focusing on employer sanctions and marriage fraud and concluding that criminal sanctions are an inappropriate deterrent); Teresa A. Miller, Blurring the Boundaries Between Immigration and Crime Control After September 11,25 B.C. THIRD WORLD L.J. 81, 85 (2005) (highlighting the social control dimensions of criminalization of immigration law); Teresa A. Miller, Citizenship and Severity: Recent Immigration Reforms and the New Penology, 17 Geo. IMmiGr. L.J. 611, 660 (2003) (seeking to explain why criminal law and immigration law are converging and why now); Teresa A. Miller, Lessons Learned, Lessons Lost: The Immigration Enforcement's Failed Experiment with Penal Severity, 38 FordHAM URB. L.J. 217 (2010) (discussing how the criminal justice system has reduced its excesses more than immigration enforcement system); Juliet Stumpf, The Crimmigration Crisis: Immigrants, Crime, and Sovereign Power, 56 AM. U. L. REv. 367 (2006) (exposing a common link, rooted in membership theory, that increasingly unites these two once discrete fields of law), cited in Stephen H. Legomsky, The New Path of Immigration Law: Asymmetric Incorporation of Criminal Justice Norms, 64 WASH. \& LEE L. REV. 469, 470 n.I [hereinafter Legomsky, Asymmetric Incorporation]; Anil Kalhan, Rethinking Immigration Detention, 110 Colum. L. Rev. SidebaR 42 (2010); Jennifer M. Chacón, Managing Migration Through Crime, 109 COLUM. L. Rev. SIDEBAR 135 (2009), http://www.columbia lawreview.org/Sidebar/volume/109/135_Chacon.pdf (arguing that the increase in immigrationrelated criminal prosecutions has resulted in lesser procedural protections in some of these criminal cases, akin to the relaxed procedural norms of civil immigration proceedings); David Alan Sklansky, Crime, Immigration, and Ad Hoc Instrumentalism, NEw CRIM. L. REV. (forthcoming 2012), available at http://papers.ssrn.com/sol3/papers.cfm?abstract_id=1912518 (describing the convergence of the immigration enforcement and criminal justice systems and arguing that this convergence both arises from and facilitates an ad hoc, instrumentalist approach to the law); Mary Bosworth, Foreigners in a Carceral Age: Immigration and Imprisonment in the U.S. (Univ. of Oxford Legal Research Paper Series, Paper No. 34/2011, 2011), available at http://papers.ssm.com/sol3/papers.cfm?abstract_ id $=1852196 \&$ download $=$ yes (describing the increased criminalization of immigration violations, the rising number of noncitizens in U.S. prisons, and the growth of immigration detention). See also infra notes $66-70$ and accompanying text on the increased prosecution of immigration offenses at the federal level and the consequences for prison overcrowding.

33. Elsewhere, I have observed that teachers of immigration law typically oppose almost any change that would make the enforcement system in general, and deportation in particular, more effective in assuring that only legally-admitted people may live and work here. See Peter H. Schuck, The Disconnect Between Public Attitudes and Policy Outcomes in Immigration, in Debating IMMIGRATION 27-28 (Carol M. Swain ed,, 2007). Mary Fan, The Crimigration Complex, 92 NoRTH CAROL. L. REv. (forthcoming 2013).

34. For a more detailed account of the criminalization of U.S. immigration law - a body of law that was once conceived as civil in nature-see supra note 32, Legomsky, Asymmetric Incorporation. Professor Legomsky also discusses the prioritization of criminal enforcement theory in immigration law, and the importation of criminal law enforcement strategies into immigration enforcement. Further, he makes a case that this criminalization has been "asymmetric," meaning that "[e]lements aligned with criminal enforcement have steadily found their way into immigration law, while the procedural safeguards at the core of criminal adjudication have been consciously rejected." $I d$. at 528 . 
critics also argue that deporting immigrants who commit crimes in the United States is usually too harsh a sanction in that it separates them from their family members (often including citizen children or spouses), ignores how American society has contributed to their criminality, and sends them back to countries to which they have only an attenuated relationship, an action that may even violate their human rights under international law. ${ }^{35}$ A number of critics of current removal practices insist that it should be (or already is) subject to a proportionality constraint. ${ }^{36}$ Although I share some of these criticisms of existing law, ${ }^{37}$ I believe that their logic does not, and should not, lead critics to oppose the reform proposals presented here, which would merely accelerate removals that presumably will occur anyway once the criminals complete their sentences.

My target audience, then, consists mostly of the larger group of people who both countenance the immediate deportation of immigrant criminals under certain circumstances (especially those who have committed relatively serious crimes), and who worry about the early release of offenders purely to alleviate overcrowding.

In principle and perhaps also in practice, this analysis is perfectly compatible with other approaches to reducing prison overcrowding, such as decriminalizing certain offenses, liberalizing parole, and establishing workable alternatives to incarceration for non-violent offenders. Deportation before imprisonment would only be one arrow in the policy reformer's quiver. Nevertheless, it is a potentially important policy change, one that has received far less attention than the others.

35. See, e.g., Melissa Cook, Bunished For Minor Crimes: The Aggravated Felony Provision of the Immigration and Nationality Act as a Human Rights Violation, 23 B. C. THIRD WORLD L. J. 293 (2003); Stephen H. Legomsky, The Alien Criminal Defendant: Sentencing Considerations, 15 SAN Diego L. REv. 105, 137 (1977) (cautioning against deportation on criminal grounds except when the noncitizen's presence after release would pose an unusually serious danger to the general public). See also T. Alexander Aleinikoff \& Margaret H. Taylor, Deportation of Criminal Aliens: A Geopolitical Perspective, Inter-Am. Dialogue at 13 (May 1998), available at http://www.iadialog.org/ taylor.html, 13 (citing the problems inherent in increases in criminal immigrant deportations, for both the United States and the receiving countries, including the strengthening of international crime syndicates, lack of cooperation by receiving countries, and corrosion of the rule of law in receiving countries). Legal philosopher Jeremy Waldron has expressed this view especially strongly and eloquently. Jeremy Waldron, Remarks at Faculty Workshop at the New York University School of Law (AuG. 11, 2011).

36. E.g., Angela M. Banks, Proportional Deportation, 55 WAYnE L. REv. 1651 (2009); Michael J. Wishnie, Immigration Law and the Proportionality Requirement, available at http://ssrn.com/ abstract $=1952252$.

37. See, e.g., Peter H. Schuck, Citizens, Strangers, And In-Betweens: Essays On ImmigraTION AND CITIZENSHIP 144-45 (1998) ("Much in this new law is harsh and unjust, will have perverse effects, and needs to be changed."). 


\section{Immigrant Criminals and Prison Overcrowding}

\section{A. Magnitude of Immigrant Incarceration}

According to recent federal data, a reported 102,809 non-U.S. citizens were held in federal and state prisons at year-end $2011 .{ }^{38}$ Non-U.S. citizens represent between $17 \%$ and $26 \%$ of the federal prison population, roughly $4 \%$ of the total state prison population, and they occupy significant space in local jails as well. ${ }^{39}$ ICE estimates that up to 450,000 deportable immigrants are in the criminal justice system each year. ${ }^{40}$ ICE estimates that as of 2011 , there were 208,613 removable criminal immigrants incarcerated, as well as $1,974,049$ criminal immigrants who had a criminal conviction but were not at that time detained by any law enforcement agency-for example, because they had been paroled or granted probation from a correctional institution. ${ }^{41}$

To be sure, the dimensions of the crime problem in the United States have changed over time, along with the mix of offenses for which criminals are incarcerated. The incidence of violent crime in the United States in 2009 was

38. At year-end 2011, states reported having 72,265 immigrants in their prisons. E. ANN CARSON \& William J. Sabol, U.S. Dep't OF Justice, Bureau of Justicle Statistics, Prisonisks in 2011, at 13 (Dec. 2012). ICE estimates are even higher: ICE estimates that there were 86,810 non-U.S.-citizens incarcerated in state prisons in 2009. At the federal level, the Federal Bureau of Prisons reported that 58,300 non-U.S. citizens were incarcerated in federal prisons in January 2012. See Appendix 1.

39. According to the Federal Bureau of Prisons, 74\% of the federal prison population were U.S. citizens. Quick Facts About the Bureau of Prisons, FED. BUREAU Ol: PrIsons, available at hitp:// www.bop.gov/news/quick.jsp (last updated June 29, 2013). The Bureau of Justice Statistics indicates that non-citizens were $17 \%$ of the federal prison population. CARSON \& SABOL, supra note 38, at 14. At midyear 2008, 2,363 out of approximately 2,829 jail jurisdictions nationwide reported on the number of non-U.S. citizens in their custody to the Bureau of Justice Statistics' annual mid-year survey of the nation's jails. The reporting jurisdictions reported that 47,934 non-U.S. citizens were in their custody, or $9 \%$ of their total population. TODD D. MINTON \& WILLIAM J. SABOL, U.S. DEIT. OH: Justice, Bureau of Justice Statistics, Jall. Inmates at Midylir 2008-Statistical. Tablass 6 (2009). It should be noted however, that these population statistics represent a snapshot in time and do not reflect the total number of non-U.S. citizens that are incarcerated per year, particularly at the county level, due to the relatively short sentences. Although the same basic annual survey was conducted for 2009 and 2010 as well, jails in that survey were not asked to report on the number of non-U.S. citizens in their custody.

40. Comm. on appropriations, Fact Shlet: Enhanced Border ani) Immigration Siecurity (2010). The total detained criminal immigrant population in FY 2007 was estimated to be approximately 630,000 nationwide, with an additional 275,000 immigrants in the United States illegally. Dept. of Homeland Sec. Appropriations for Fiscal Year 2007: Hearings Before a Subcomm. of the S. Comm. on Appropriations, 109th Cong. 453 (2006).

41. Immigration and Customs Enforcement, Criminal Aliten Statistics, (Mar. 15, 2011) (on file with author); E-mail from John A. Schultz, Immigration and Customs Enforcement, to Talia Kraemer, Yale Law School (Feb. 21, 2012, 4:43 PM EST) (on file with author). Of the incarcerated removable population, 85,707 are incarcerated for Level I offenses (which include homicide, kidnapping, robbery, major drug offenses with sentences greater than one year, threats to national security, and other crimes against persons); 91,077 are incarcerated for Level 2 offenses (which include mainly property crimes such as larceny, fraud, arson, and smuggling); and 31,829 are incarcerated for Level 3 offenses (which include all other crimes). Id.; ICE SECURE COMmUNITIIs, Talking Points, Police Executive Research Forum, Jan. 12, 2010, available at http://www.ice.gov/ doclib/foia/secure_communities/talkingpointsjanuary 122010.pdf. Of the at-large population, 811,019 are Level 1 offenders, 861,842 are Level 2 offenders, and 301,188 are Level 3 offenders. IMMIGRATION and Customs Enforcement, Criminal Alien Statistics, (Mar. 15, 2011) (on file with author). 
the lowest it had been since $19844^{42}$ The incidence of property crime in 2009 was the lowest it had been since $1974 .{ }^{43}$ In New York City, a gateway for immigrants, the decline has been even more dramatic. ${ }^{44}$

A significant number and proportion of those who are incarcerated, both citizens and immigrants, are there for drug-related offenses: $47.2 \%$ of federal inmates and $17.8 \%$ of state inmates. ${ }^{45}$ Although a growing number of Americans believe that many drug-related offenses either should be decriminalized, or if retained as crimes, should not result in significant, if any, prison

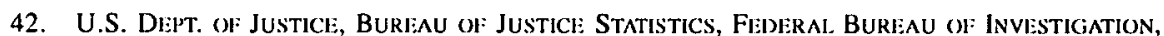
Uniform Crime Riporting Statistics-Estimated Violint Crimi: Total, available at http:// www.ucrdatatool.gov/Search/Crime/State/RunCrimeTrendsInOneVar cfm (last visited June 27, 2013).

43. U.S. Dept. of Justice, Burlan ol Justice Statistics, Figdiral. Burian of Invistigntion, Unilorm Crimi: Riporting Statistics-Estimated Propierty Crim: Total, available at http:// www.ucrdatatool.gov/Search/Crime/State/RunCrimeTrendsInOneVar.cfm (last visited June 27, 2013).

44. See Frankin E. Zimring, ThE Great American Crime Decl.ine 137 (2007) (finding that between 1990 and 2000, the drop in crime in New York City was almost exactly twice the crime decrease in the rest of the United States). Between 1990 and 2000, New York City experienced dramatic drops in seven key index offenses: homicide dropped by $73 \%$, rape by $52 \%$, robbery by $70 \%$, aggravated assault by $46 \%$, burglary by $72 \%$, auto theft by $78 \%$, and larceny by $52 \%$. Id . New York's crime ranking relative to the other 9 of the 10 largest U.S. cities also decreased during this period. While in 1990, New York had the highest or second highest crime rate in four of the above seven crime categories. By 2000 , New York was below average in all seven offense categories and had the lowest crime rate of the 10 largest U.S. cities in five of the seven offense categories. Id. at 141 . More recently, Zimring found that New York's crime rates continued to decline during the period from 2000 to 2009. Franki.in E. Zimring, Thi: City That Biacami: Sali:: Nizw York's Lisssons loor URBAN CRIMl: ANI) ITS Control. 5-6 (2012). Between 2000 and 2009, homicide dropped by an additional $33 \%$, rape by $51 \%$, robbery by $46 \%$, assault by $38 \%$, burglary by $52 \%$, auto theft by $72 \%$, and larceny by $23 \%$. Id . at 6 . New York's continued crime decline is notable in part because other major U.S. cities have not experienced such consistent declines over the same period. Of the ten largest U.S. cities outside of New York, seven of the cities had a mix of increasing, steady, and declining crime rates across the major index crime categories from 2000 to 2009. Id. at 15 . However, in most of these cities, crime rates in 2009 remained below the 1990 level. Id.

New York's decline has continued through 2010, with the New York City Police Department's CompStat data system reporting that New York has experienced the following percentage declines in crime complaints between 1993 and 2014: murder-78.3\%; rape-54.7\%; robbery-82.6\%; felony assault- $53.0 \%$; burglary-85.3\%; grand larceny-51.5\%; grand larceny auto-94.5\%. CoMlSTAT CitYwide: CRIME STATISTICS W I:IKI.Y, 1/6/2014 through 1/12/2014, available at http://www.nyc.gov/ $\mathrm{html} / \mathrm{nypd} /$ downloads/pdf/crime_statistics/cscity.pdf. The validity of the CompStat data has been questioned and is being investigated. See Al Baker \& William K. Rashbaum, New York City to Examine Reliability of Its Crime Statistics, N.Y. TIMıs, Jan. 5, 2011. Zimring has used external statistical sources to confirm that the crime drops shown by the CompStat numbers are valid for at least three key index crimes. For homicide, Zimring's independent analysis reflects a crime drop matching the CompStat numbers nearly exactly. For robbery and auto theft, Zimring's sources confirm a significant drop but do not match up exactly to the CompStat numbers. See Thi Criminal. Justice Conversations PodCast with David Onek, Episode \#11: Frank Zimring, Professor, Berkeley Law School at 05:00-08:00, BERKLI.EY LAW (May 11, 2010), http://www.law.berkeley.edu/ 8357.htm.

45. See Appendix 2. At the federal level, as of January 28, 2012, 48.9 percent of the prison population was incarcerated for drug offenses, $15.6 \%$ for weapons, explosives, or arson crimes, 12.2\% for immigration violations, $4.2 \%$ for robbery, $3.7 \%$ for burglary, larceny or property offences, $5.5 \%$ for extortion, fraud, or bribery offenses, $2.8 \%$ for homicide, aggravated assault and kidnapping offences, and $5.2 \%$ for sex offenses.

At the state level, on December $31,2010,53.2 \%$ of inmates were serving time for violent offenses, $18.3 \%$ for property offenses, $17.4 \%$ for drug offenses, $10.5 \%$ for public order offenses, and $0.6 \%$ for "other" offenses. CARSON \& SABOL., supra note 38, at 28. Combining the state and federal prison populations from 2009, just under $22 \%$ of inmates were serving time for drug offenses. See Appendix 2. 
time,${ }^{46}$ this view has not yet made significant political headway. ${ }^{47} \mathrm{~A}$ fact that is highly relevant to the decriminalization debate is that relatively few of those in prison for drug law violations today are there solely because of their use or possession of amounts suitable for personal consumption; almost all federal drug law offenders are incarcerated for relatively serious crimes. Jonathan Caulkins, a leading authority on the subject, notes that most of those whose controlling offense is simple possession admit on the prison inmate surveys that they were in fact involved in distribution, but then managed to plea-bargain down to simple possession. The distribution of offense types for non-citizens incarcerated in U.S. prisons for drug law violations is broadly similar to that of their citizen counterparts, albeit with predictable differences. For example, immigrant drug offenders in federal prisons are more likely to report that they were involved in importation and thus possession of larger quantities. ${ }^{48}$

Immigration-related crimes constitute another important category, although smaller than one might think. Approximately $12 \%$ of federal inmates are imprisoned for immigration offenses. ${ }^{49}$ In $2009,93.4 \%$ of those incarcerated for immigration offenses were non-U.S. citizens, and $6.6 \%$ were U.S. citizens. ${ }^{50}$ Of the 20,470 non-U.S. citizens incarcerated in federal prisons for immigration offenses, $83.6 \%$ were convicted of unlawfully entering or remaining in the United States. ${ }^{51}$ An additional $8.2 \%$ were incarcerated for

46. See, e.g., David Boyum \& Peter Reuter, An Analytic Assessment of U.S. Drug Policy (American Enterprise Institute, 2005) (describing the failures of the current drug policy framework which focuses on enforcement and incarceration rather than treatment, and arguing that the current policy framework should be reoriented to stop incarcerating low-level dealers); The Hon. Michael A. Wolff, Evidence-Based Judicial Discretion: Promoting Public Safety Through State Sentencing Reform, 83 N.Y.U. L. REv. 1389, 1413 (2008) (speaking to the effectiveness of special drug courts. "We still send many offenders to prison for drug offenses, but drug courts have shifted the focus for many offenders from punishment to rehabilitation."); Alternatives to Prohibition, THE DRUG POLICY ALLIANCE, http://www.drugpolicy.org/drugwar/alternatives/, (last visited Jan. 25, 2014) (advocating for a "harm reduction" principal to serve as the foundation of drug policies moving forward, meaning that "people should not be punished for what they put into their bodies, but only for crimes committed against others.").

47. For example, in November 2010 , California voters rejected a measure that would have made California the first state in the country to allow marijuana to be sold for recreational use. The November 2010 vote was the second time within two years that California voters rejected a ballot initiative that would have reduced penalties for drug crimes. See John Hoeffel \& Maria L. La Ganga, Youth Vote Falters; Prop. 19 Falls Short, L.A. Times, Nov. 3, 2010, at A17; see also Gonzales v. Raich, 545 U.S. 1, 15 \& n.23 (2005) (discussing "considerable efforts," ultimately unsuccessful, to have marijuana rescheduled as a Schedule III drug under federal law). But see Nathan Koppel \& Gary Fields, States Rethink Drug Laws, WALL ST. J., Mar. 5-6, 2011, at A3; Happy Toking, The EconomiST, Feb. 12, 2011, at 38 (small but increasing majorities favor legalization of marijuana); Frank Newport, Record-High 50\% of Americans Favor Legalizing Marijuana Use, GalLuP, Oct. 17, 2011, http:// www.gallup.com/poll/150149/record-high-americans-favor-legalizing-marijuana.aspx.

48. Jonathan P. Caulkins \& Eric Sevigny, The Effects of Drug Enforcement and Imprisonment on Transit Countries: The Case of the U.S. and Mexico (Appendix C to Sidney Weintraub \& Duncan Wood, CoOperative Mexico-U.S. AnTinarcotics EFForTs 99-127, Center for Strategic and International Studies, Washington, DC (2010)).

49. Appendix 2.

50. Pew Center, Descriptive Statistics for Federal Immigration OfFenders by Citizenship STATUS, (2009) (on file with author).

51. Id. 
smuggling, transporting, or harboring an unlawful alien, and $7.3 \%$ were incarcerated for fraudulently acquiring documents, false impersonation, or fraudulent marriage to evade immigration law. ${ }^{52}$ Of the 1,442 U.S. citizens incarcerated for immigration offenses in 2009, the vast majority-92\%were convicted of smuggling, transporting, or harboring an unlawful alien. ${ }^{53}$

Many immigrants are incarcerated for more serious crimes carrying substantial prison sentences. ${ }^{54}$ The recent trend in a number of states to de-criminalize minor drug offenses or to reduce the criminal penalties for them, ${ }^{55}$ suggests that those immigrant criminals who are incarcerated today may be likely to have committed more serious crimes than those immigrants incarcerated in the past. James Forman, Jr., writing of incarcerated criminals generally, not just immigrant inmates, observes, "Considering all forms of penal institutions together, more prisoners are locked up for violent offenses than for any other type.... [E]ven if every single [drug offender] were released tomorrow, the United States would still have the world's largest prison system." 56

Immigration law makes many incarcerated immigrants deportable because of the nature or number of their crimes, ${ }^{57}$ although data limitations make it

52. Id. Of the federal immigration offenses committed by Hispanic inmates in $2007,12.5 \%$ were for smuggling, transporting, or harboring an unlawful alien; more than $81 \%$ were for unlawful entry or presence. See Appendix 2.

53. See supra note 50.

54. See E. ANn Carson \& William J. Sabol, supra note 38 for statistics on offense breakdowns on non-citizen inmates. Even assuming that those non-citizens incarcerated for immigration violations are incarcerated only for immigration violations and not for other crimes as well, this means that over half of the immigrant federal prisoner population is serving time for other crimes. Although most of these are probably drug offenses, it follows that many are more serious. See also BOP: Statistics, supra note 39. For offense breakdowns in some state prison systems, see Appendix 2.

55. See, e.g., Koppel \& Fields, supra note 47; Jesse McKinley, California Reduces Its Penalty for Marijuana, N.Y. TIMEs, Oct. 1, 2010, at A9 (reporting Gov. Schwarzenegger's signing of a bill on Sept. 30, 2010 that reduces the crime of possession of small amounts of marijuana from a misdemeanor to an infraction); Abby Goodnough, Marijuana Law Comes With Challenges, N.Y. TIMES, Dec. 17, 2008 (reporting the implementation of a Massachusetts law passed by referendum in the November 2008 elections reducing possession of small amounts of marijuana from a crime to a civil infraction; at that time eleven other states including New York and Nebraska had similarly decriminalized first-time possession of marijuana); Drug Penalty Reduction and Decriminalization Efforts, 37 Prosecutor 35, 36 (Sept./Oct. 2003) (surveying the proposals of various decriminalization and penalty reduction laws considered during the 2002 elections, including Kansas Senate Bill 123, was signed by the governor on April 21, 2003, and provided that "certified drug abuse treatment would be provided to certain eligible offenders in lieu of incarceration in prison."). See generally Matthew Briggs, Katharine Huffman, Rebecca lubot-Conk \& Blll Piper, Drug Policy Alliance, State of the States: Drug Policy Reforms: 1996-2002, at 42 (2003) (listing state law changes on treatment instead of incarceration, legalization of medical marijuana, sentencing reform, and other drug policies).

56. James Forman, Jr., Racial Critiques of Mass Incarceration: Beyond the New Jim Crow, 87 N.Y.U. L. REV. 21,47 (2012).

57. See Immigration and Nationality Act of $1965 \S 237(a)(2), 8$ U.S.C. $\$ 1227(a)(2)(2006)$; Gordon et al., supra note 19 . The Supreme Court recently recognized that a very large proportion of immigrants who are convicted of crimes are subject to deportation. See Padilla v. Kentucky, $130 \mathrm{~S}$. Ct. 1473 (2010) ("The landscape of federal immigration law has changed dramatically over the last 90 years. While once there was only a narrow class of deportable offenses and judges wielded broad discretionary authority to prevent deportation, immigration reforms over time have expanded the class of deportable offenses and limited the authority of judges to alleviate the harsh conse- 
impossible to know the precise number or percentage of this population who are in that situation. ${ }^{58}$ Once convicted, immigrant criminals are unlikely to have any viable defense to deportation unless they can establish fear of persecution in the destination country or can qualify for a discretionary waiver. ${ }^{59}$ ICE, like its predecessor INS, has been keen to remove criminal immigrants immediately upon their release from prison under its CAP program, which seeks to identify criminal immigrants while they are still in federal, state and local prisons, and assure that these individuals are taken into ICE custody at the completion of their criminal sentences. ${ }^{60}$ Although this program has succeeded in removing a growing number of immigrant criminals, many still end up slipping through the agency's notoriously ragged enforcement net and disappear at the end of their prison terms before the agency can effectuate their deportation. ${ }^{61} \mathrm{CAP}$ has been found to reduce costs for those immigrant criminals whom it reaches, but it has long been underfunded and understaffed. ${ }^{62}$

The spotty record of the CAP/IRP supports arguments both for pre or

quences of deportation. The 'drastic measure' of deportation or removal, Fong Haw Tan v. Phelan, 333 U.S. 6, 10 (1948), is now virtually inevitable for a vast number of noncitizens convicted of crimes.").

58. Appendix 2 explains why this is so.

59. Many of the forms of relief available to immigrants determined to be removable are not available to immigrants convicted of aggravated felonies, or crimes that would render them deportable. See generally, Legomsky \& Rodriguez, supra note 1, chap. 8. For a description of how the forms of relief traditionally available to immigrants have been curtailed over the past several decades, and the limited forms of relief currently available, see Schuck \& Williams, supra note 30, at 392-94.

60. 8 U.S.C. $\$ 1228(a)$. Of special interest for the current analysis is subsection $1228(\mathrm{a})(3)(\mathrm{B})$, which provides that "Nothing in this section shall be construed as requiring the Attorney General to effect the removal of any alien sentenced to actual incarceration, before release from the penitentiary or correctional institution where such alien is confined."

61. See, e.g., Julia Preston, 596 Arrested in Sweep, N.Y. TıMEs, May 1, 2010, at A12 (reporting that the head of ICE says many of the immigrants apprehended in a recent raid had eluded deportation when released from prison after serving criminal sentences).

62. A recent OIG audit found, based on a sample of cases, that CAP successfully identified $99 \%$ of removable criminal aliens in federal custody during FY 2009. U.S. DI:P'T OF HOMELAND SECURITY, OfFICE of INSPECTOR General, OIG-11-26, U.S. IMMigration and Customs EnForClimint IDIENtification of Criminal. Al.iens in Fediral. anis Stati: Custody Ei.jgible for Removal hrom the UNITED STATES 4 (2011). The audit also sampled cases to review CAP performance at the state level in California, Florida, New York, and Texas, the four states with the highest number of foreign-born inmates in state prison. Id. Of the sampled cases, the audit found that CAP had identified $96 \%$ of criminal immigrants eligible for removal in California and $98 \%$ of eligible inmates in Texas. Id. at 5. CAP had identified all removable noncitizen inmates in the Florida and New York samples. Id. at 6. The audit raised concerns, however, that CAP may not be able to maintain this high level of performance unless it increases staffing levels. Id. Currently, CAP has multiple unfilled staff positions, and CAP's workload is expected to increase due to referrals from the Secure Communities Program. Id. Moreover, the removable criminals in the sample whom CAP did not identify were all Level I criminals and were believed to pose a significant public safety risk. $I d$. at 7 . This audit demonstrates great improvement in the CAP's effectiveness during the last decade. A 2002 Audit Report found that the IRP was severely underfunded, poorly managed, and overworked. U.S. DisT. ol: JUSTICE, Audit Report: Immigration and Naturalization Siervice Institutional Rigmoval. Progiram i-iv (Sept. 2002). 
early-incarceration deportation and for strengthening the CAP itself. ${ }^{63}$ Indeed, even if the CAP worked perfectly, prudent policy would seek to minimize two large costs to which even such a perfect CAP would contribute: avoidable incarceration costs, and unconstitutional over-crowding.

In sum, immigrant criminals serving time in federal, state and local prisons and jails constitute a large number of inmates, and also a substantial percentage of all inmates. Although we do not know the number or percentage of these immigrant inmates who are either immediately removable or who may have viable defenses to, or discretionary waivers from removal, the immediately removable group's share of the total incarcerated population is certainly large enough to warrant this conclusion: removing immigrant criminals before they are actually imprisoned or early in their prison terms would create significant financial savings to our prison and detention systems, and would reduce overcrowding in those systems that is dangerous, arguably inhumane and unconstitutional. ${ }^{64}$ The next section focuses on another reason why earlier removal of immigrant criminals should be an important policy goal: the enormous pressure that prison overcrowding has created to release criminals prematurely, at some risk to public safety.

\section{B. Prison Overcrowding}

The over-crowding of U.S. prisons has been a matter of great legal, political and administrative concern at both the federal and state levels for a very long time. The commonly-noted causes are longer sentences, high recidivism rates, the wars on drugs and illegal immigration, extended prisoner lifespans, limits on parole and other factors. ${ }^{65}$ Recent research, however, indicates that the main cause is not longer sentences but more admissions, many of them with short-term sentences. ${ }^{66}$

Prison overcrowding continues today despite the fact that in 2010 the total prison population (federal and state) declined (slightly) for the first time since

63. See Feb. 2011 report by Inspector General for DHS, summarized in, Edwin Mora, ICE Allowed the Release of 890 Imprisoned Deportable Aliens, Convicted of Serious Crimes, Into U.S. in FY 2009, CNS Nisws, Feb. 9, 2011, hitp://www.cnsnews.com/print/81196.

64. See, e.g., Brown v. Plata, 131 S. Ct. 1910 (2011).

65. See generally, ERnist Drucki: A Plagul: ol: Prisons: Thl Elidemiology of Mass Incarciration (2011). On life sentence terms, see Rachel E. Barkow, Life Without Parole and the Hope for Real Sentencing Reform 8 (Feb. 2011) (unpublished Manuscript) (on file with the Georgetown Immigration Law Journal) ("Roughly 1 in 11 incarcerated individuals (more than 140,000 people) in the United States are serving a life term."); AshLI:Y Nel.lis \& RYAN S. KinG, No Exit: The Exiranding Ust of Lif: Sintincles in Ami:Rica 3 (2009), available at hitp://www. sentencingproject.org/doc/publications/publications/inc_noexitseptember2009.pdf).

66. John F. Pfaff, The Myths and Realities of Correction Severity: Evidence from the National Corrections Reporting Program on Sentencing Practices, 43 AM. ECoN. L. Rl:v. 491-531 (2011). According to Pfaff, the contribution to overcrowding of readmissions after parole violations, while significant in California, is unclear elsewhere. E-mail from John F. Pfaff, Assoc. Prof. Fordham Law to author (Feb. 21, 2012) (on file with author). 
$1972 .{ }^{67}$ Many factors explain the persistence of overcrowding, which is worsening in some respects.

First, although the combined state and federal prison population declined in 2010 , the federal prison population has continued to grow. ${ }^{68}$ The combined state and federal prison population has declined for the past three years. This decline was largely driven by reductions in state prison populations. ${ }^{69}$ The federal prison population has continued to grow-more than doubling since $1995^{70}$-and reaching a total of 215,965 in $2014 .{ }^{71}$ It experienced an average annual increase of approximately 4 percent between 2000 and 2009, an increase of $0.8 \%$ from 2009 to 2010 , and an increase of $3.1 \%$ from 2010 to $2011 .^{72}$ On December 31, 2012, the federal prison system was operating at $138 \%$ of its highest capacity. ${ }^{73}$ In general, the federal system has tougher sentencing laws, more restrictive supervision policies and fewer opportunities for diversion of defendants to alternative programs.

Increased prosecution of immigration offenses is also a key contributor to federal prison population growth and overcrowding. According to the Pew Prison Count, "increased prosecutions of immigration offenses help to explain the divergent trends between most states and the federal system. Prior to 1994 , relatively few immigration cases in the federal courts reached sentencing, but by 2008 they accounted for 28.2 percent of all federal sentences, amounting to more than 21,000 individuals." 74 According to Bureau of Justice Statistics, the number of immigration offenders in federal prison increased nine-fold from 1,593 inmates in 1985 to 13,676 inmates in $2000 .^{75}$ Over that period, the incarceration rate and sentence length of immigration offenders also increased sharply due to changes in federal

67. Paul Gulerino, Paige harrison, \& William J. Sabol, U.S. Dep't of Justice, Bureau of Justice Statistics, Prisoners in 2010 l (2011). The state prison population dropped in 2009 for the first time since 1972. However, the combined federal and state prison population increased in 2009. Pew Center on the States, Prison Count 2010: State Population Declines for the First Time in 38 YEARS 1 (2010) available at http://www.pewcenteronthestates.org/uploadedFiles/Prison_Count 2010.pdf? $\mathrm{n}=88010$, [hereinafter Pew Prison Count]. See generally, Charlie Savage, Trend to Lighten Harsh Sentences Catches On in Conservative States, N.Y. TIMEs, Aug. 13, 2011, at Al 4.

68. See CARSON \& SABOL, supra note 38

69. U.S. Prison Population Drops for Third Year as States Adopt New Policy Strategies, PEw Center Public Safety Performance Project, http://www.pewstates.org/news-room/press-releases/ us-prison-population-drops-for-third-year-as-states-adopt-new-policy-strategies-85899496150 (last updated August 8, 2013).

70. Pew Prison Count, supra note 67, at 5 .

71. BOP: Population Statistics, FED. Bureau of PrISONS, http://www.bop.gov/about/statistics/ population_statistics.jsp (last visited January 23, 2014).

72. See Guerino ET Al., supra note 67, at 2. See also, CARSON \& SABOL, supra note 38, at 3.

73. See CARSON \& SABOL, supra note 38 , at 31 . The highest capacity refers to the maximum number of beds reported across the three capacity measures: design capacity, operational capacity, and rated capacity. Id. at 18 .

74. Pew Prison Count, supra note 67, at 5 .

75. John Scalia \& Marika F.X. Litras, U.S. Dep't of Justice, Bureau of Justice Statistics, Immigration Offenders in the Federal Criminal Justice System, 2000, at 2, 8 (2002). For these offenders, the immigration offense was the most serious offense for which the immigrant was incarcerated. 
sentencing policy. ${ }^{76}$ The incarceration rate for immigration offenders increased from $57 \%$ to $91 \%$, and the average time served increased from 3.6 months to 20.6 months. ${ }^{77}$ The increase in incarcerated immigration offenders accounted for $14 \%$ of overall federal prison population growth during that time period. ${ }^{78}$ The percent of noncitizens in federal prisons also increased during that time, from $14 \%$ to $29 \%$ of the federal prison population. ${ }^{79}$

Third, the recent decline in the overall prison population likely obscures the extent to which overcrowding problems remain. An important variable is how overcrowding is defined. Conventionally, it is defined in terms of the percentage that the prison census bears to a facility's "operational capacity." According to the Vera Institute, "[Official], [c]onservative measures show a decline in crowding nationally among state prisons-from 114 percent of their highest, 'operational' capacity in 1995 to 99 percent in 2004. A less conservative measure, based on institutional design, shows that facilities were operating at 115 percent of their capacity in 2004." ${ }^{80}$ As I note below, California has been operating at about 166 percent of capacity, despite being under a court order to reduce its overcrowding. ${ }^{81}$ The Vera Institute also notes, "[c]orrections administrators define the operational capacity of their own facilities by drawing on a number of factors to ensure that living

76. Id. at 2 ("Increased prosecutions and changes to sentencing policy have had a substantial effect on the size of the Federal prison population.")

77. Id. at 2,10 .

78. Id. at 2 .

79. Id. at 8 .

80. Vera Institute of Justice, CONFRONTING CONFinement: A RePort of the Commission on SAFETY AND ABUSE IN AMERICA's PRISONS 26 (June 2006), http://www.vera.org/download?file $=2845 /$ Confronting_Confinement.pdf. There are three methods of rating prison capacity, and therefore overcrowding, according to Bureau of Prisons (BOP) statistics. "Rated capacity is the number of beds or inmates assigned by a rating official to institutions within the jurisdiction. Operational capacity is the number of inmates that can be accommodated, based on a facility's staff, existing programs, and services. Design capacity is the number of inmates that planners or architects intended for the facility." U.S. DeP'T OF Justice, Bureau of Justice Statistics, Bull. NJC 210677, Prisoners in 2004, at 7 (2005), http://bjs.ojp.usdoj.gov/content/pub/pdf/p04.pdf [hereinafter PRISONERS IN 2004]. The "conservative" estimate referred to by the Vera report is the estimate of population as a percent of total capacity based on the lowest of these measures for the states and for the federal prison system combined. The "less conservative" estimate is the estimate of total population as a percent of total capacity based on the highest of these measures for the states and for the federal prison system combined. In general, it seems that the "design capacity" is typically lower than the "rated capacity" or the "operational capacity." This suggests that the architects and designers of the prison complexes anticipated many fewer inmates per unit of physical space, regardless of the amount of other resources that might be pumped into the facilities to manage the growing prison populations. The second highest measure of the three is typically the rated capacity. This measure is higher than the design capacity in part because of the increasing practice of double- and triple-celling prisoners. The highest measure of capacity is typically the "operational capacity" and this measure is based on BOP's assessment of the volume of staff, programs, and services within a facility; it seems that this measure is independent of actual physical space, and of course is based on the subjective assessment of the facility assessors, which probably leaves room for inflation. Significantly, these aggregate measures fail to capture the tremendous variation among states.

81. This number comes from a calculation from the California Department of Corrections and Rehabilitation (CDCR) reported figures. According to the CDCR, the design capacity is 79,858 . The current population figure is 132,831. Cal. Dep't of Corrections and Rehabilitation, Weekly Population Figures, http://www.cdcr.ca.gov/realignment/3jp-chart.html (last visited July 7, 2013). 
conditions and services at least meet constitutional standards." 82 But, "[i]n reality, corrections administrators are often under pressure from county and state executives and legislators to raise their operational capacity and sometimes to exceed it." ${ }^{83}$ I suggest that prison administrators' own bureaucratic incentives probably cut the other way, in favor of a lower rating capacity that can help establish their claims of overcrowding and attract more funding to ameliorate the poor conditions in their facilities that overcrowding produces. $^{84}$

Fourth, many corrections administrators believe that running at more than $90 \%$ of their system's operational capacity deprives them of necessary flexibility. ${ }^{85}$ Recognizing the considerable variation among states and localities in levels of crowding, the majority of prisons and many jails are overcrowded by that $90 \%$ standard. "The average American prisoner lives in an environment roughly the size of a king-size bed," psychologist and prison consultant Craig Haney reported in $2006 .{ }^{86}$ "He concluded that when crowding is understood as much more than squeezing more beds into a cell or unit, American prisons are "woefully overcrowded." 87

Fifth, a Vera Institute report explains other reasons why the decline in state crowding statistics can be misleading and why the problem remains serious:

One explanation for the decrease in crowding by official counts is that institutions increased their capacity by double- and triple-celling prisoners. Professor Craig Haney testified that when he began studying prisons 30 years ago, double-celling was regarded by academics and corrections administrators as an 'unmitigated evil.' 'Nothing has changed except for the numbers of people that we have in prison to shift that judgment. Nothing has changed in academia to suggest that crowding is not harmful,' he said. Still, the entire decrease in crowding cannot be explained by this shift in practice. Even measured against a facility's original 'design capacity,' a number that never changes, crowding declined from 125 percent of capacity in 1995 to 115 percent in 2004. ${ }^{88}$ Many systems expanded their capacity by building new facilities and, in terms of available bed space, are less crowded than they were 10 years ago. So, why are we still concerned about crowding?

Crowding can occur even when facilities are less than full, as a result of circumstances ranging from a rise in the number of high-risk

82. VERA INSTITUTE OF JUSTICE, supra note 80 , at 26.

83. Id.

84. Cf. Ross Sandler \& David Scholnibod, Dimocracy by Decrili 131-32, 170 (2003) (describing institutional litigation cases in which defendants resist efforts to terminate court supervision in order to continue to benefit from increased budget allocations to their departments that resulted from the court decree).

85. See VERA INSTITUTE OF JUSTICE, supra note 80 , at 27.

86. Id.

87. Id.

88. PRISONERS IN 2004, supra note 80. 
prisoners who need their own cells to a broken water pipe that makes cells uninhabitable. Equally important, crowding is about more than physical space. Systems that now double-cell prisoners or that have added beds have not necessarily been able to make parallel increases in numbers of staff and in productive activities, two factors that affect safety. This suggests that the data on crowding do not capture the problems created by adding more and more people to a facility or system.

Finally, national numbers mask variation among the states. While some state systems are less crowded by conventional measures, some of the largest systems are more crowded. California, the nation's thirdlargest prison system, is currently at twice its capacity by some estimates, and the Federal Bureau of Prisons, the largest system, is at 140 percent of its capacity. Furthermore, some state systems are simply shifting the problem by increasingly leaving larger numbers of sentenced prisoners in local jails. ${ }^{89}$

Sixth, "overcrowding," according to Haney, "is measured by more than just the ratio of prisoners to rated capacity." "It also includes the extent to which a prison, or prison system, houses more prisoners than it has the adequate infrastructure to accommodate. ${ }^{91}$ "[M]any prison systems have increased their rated 'capacity' over the last thirty years without commensurate increases in programming, medical, and mental health resources. These systems are 'overcrowded,' even though, ... they do not house greater numbers of prisoners than [their rated capacities]."92

Seventh, the national focus on prison populations obscures the enormous growth in jail populations. ${ }^{93}$ Jail populations are actually growing faster than prison populations. ${ }^{94}$ Public attention has been focused on prisons, with increased support for reducing prison spending, sentencing reform, and treatment, rather than incarceration for drug addiction. However, the same attention has not been paid to jails and the impact that they have on the people held in them, the communities surrounding them, and the counties that must bear the financial burden. Since 2001, jail population growth exceeded prison growth, with a slight reversal in 2006. ${ }^{95}$ Between 2001 and 2006, prison populations grew 11 percent, while jail populations grew 21 percent. At

89. See VERA INSTITUTI: OI: JUSTICE, supra note 80, at 104 (Testimony of Craig Haney).

90. Craig Haney, The Wages of Prison and Overcrowding: Harmful Psychological Consequences and Dysfunctional Correctional Reactions, 22 WASH. U. J.L. \& PoL'Y 265, 266 (2006).

91. Id.

92. Id. at 266-67.

93. The following discussion of jails is taken almost verbatim from AMANDA PI:TTERUTI \& Nastassia Wal.sh, Justicl: Pol.icy Instituti: Jall.ing Communities: The Impact of Jail. Expansion ANI EFiletivi: Public SAFETY STRATEgilss 2- 12 (2008), http://www.justicepolicy.org/images/upload/ 08-04_REP_JailingCommunities_AC.pdf.

94. Id. at 2.

95. Id. 
midyear 2006, 35 of the 50 counties with the largest jail capacities had filled their jails to $90 \%$ or more. More than half of those jails reported being over capacity. As of midyear 2012, jails were operating at $84 \%$ of rated capacity. ${ }^{96}$ This was actually the lowest percentage of occupied jail capacity since $1984 .{ }^{97}$

Moreover, this increase in jail populations is linked to the overpopulation of prisons. Jails may be housing more sentenced prisoners because of overcrowding in the prison system, the inability of the corrections system to move people from jail to prison, and a shifting of responsibility for housing prisoners from the state to counties. Jails routinely lease beds to federal or state governments. As of 2005, 10 percent of the people in jail on any given day were people who had been sentenced to prison, a population that increased 16 percent in just five years. ${ }^{98}$ On December $31,2010,5.3 \%$ of all state and federal prisoners were being held in local jail facilities. ${ }^{99}$

Finally, enhanced immigration law enforcement also fuels the rise in jail populations. The heightened attention on immigration may have led to an overall increase in detention of people for immigration violations under the jurisdiction of ICE. At year-end 2006, ICE held in detention slightly over 40 percent more people than it did at year-end $2005 .{ }^{100}$ The majority of people in ICE custody are held through intergovernmental agreements in state prisons or local jails. At year-end 2006, local jails held 45 percent of the people under ICE custody, the largest portion of all facilities used by ICE. ${ }^{101}$ Jails have seen the largest increases in people held under ICE jurisdiction. From 1995 to 2006, the number of people held in local jails under ICE custody has increased more than 500 percent. ${ }^{102}$

\section{Official Responses to Prison Overcrowding}

Legal considerations aside, the budgetary stakes in relieving prison and jail overcrowding are enormous and presumably explain most of the governmental efforts to reduce it. Corrections spending represents a huge portion of state budgets. It has quadrupled in just the past 20 years, and now accounts for 1 of every 15 state general fund discretionary dollars. It has been the fastest-growing category of state budgets except for Medicaid, and nearly

\footnotetext{
96. Id.

97. Id.

98. See generally id. at 4,6,22. Another trend fueling the surge in jail populations is that more people are denied pretrial release and of those who are granted bail, fewer can afford to post it.

99. PAUL. Guerino, ET AL., supra note 67, at 32.

100. William J. Sabol, Heather Couture \& Paige M. Harrison, U.S. Dep't of Justice, Bureau of Justice Statistics, NCJ 21941 6, Prisoners in 2006, at 9 (2007).

101. Id. Subsequent versions of this report from the Bureau of Justice Statistics do not contain information on the number of ICE detainees held in local jails.

102. Id.; Sourcebook of criminal justice statistics Online, http://www.albany.edu/sourcebook/pdf/ t6612006.pdf. Subsequent versions of this table do not contain specific information on the number of ICE detainees held in local jails.
} 
90 percent of state corrections spending has gone to prisons. ${ }^{103}$

Studies have examined how much governments could save by reducing incarceration rates. One recent study claims that a reduction by one-half in the incarceration rate of non-violent offenders would lower correctional expenditures by $\$ 16.9$ billion per year and return the United States to about the same incarceration rate we had in 1993, which was already high by historical standards. ${ }^{104}$ The large majority of these savings would accrue to financially-squeezed state and local governments, amounting to about onefourth of their annual corrections budgets. ${ }^{105}$ As a group, state governments could save $\$ 7.6$ billion, while local governments could save $\$ 7.2$ billion. $^{106}$ Whether and to what extent such reductions would increase the crime rate is harder to estimate.

Whereas state corrections budgets had once been somewhat untouchable, they are now being slashed in the wake of state budgetary crises. According to one study,

[T] he budgets of at least 26 state departments of corrections have been cut for FY2010, and even those whose budgets have not been cut are reducing expenditures in certain areas.... Given that current state budget deficits are expected to continue and possibly increase over the coming years, states will need to continue to find ways to control corrections costs. Each year, the decisions will become more difficult. Management strategies may extend operating efficiencies, but the resulting cost savings are likely to fall short of what states will need to make ends meet. ${ }^{107}$

States are desperately seeking new alternatives. ${ }^{108}$

Prison overcrowding has forced some states to take extreme measures, such as reducing health services and medicine for inmates, halting construction and renovation of facilities, and reducing or abandoning valuable programs. Some have begun to close prisons altogether, although this reduces a state's overall prison capacity. For example, according to a Vera Institute study published in July 2009, Michigan Governor Jennifer Granholm announced that she would close three prisons and five prison camps,

103. Pew Prison Count, supra note 67, at 6.

104. John Schmitt, Kris Warner, \& Sarika Gupta, Center for Economic and Policy Research, The High Budgetary Cost of Incarceration 1 (June 2010), http://www.cepr.net/documents/publications/ incarceration-2010-06.pdf.

105. Id.

106. Id.

107. Christine S. Scott-Hayward, The Vera Institute, The Fiscal Crisis in Corrections: Rethinking Policies and Practices 2 (July 2009) available at http://www.pewcenteronthestates.org/ uploadedFiles/Vera_state_budgets.pdf? $n=5515$.

108. E.g., Gary Fields \& Nathan Koppel, States Seek Prison Breaks, WALl. Sr. J., Feb. 8, 2011, at A3 (describing new reforms); see also MARShall CLEMENT ET AL., supra note 12 (reporting on evidence-based strategies for increasing public safety, reducing recidivism, and reducing corrections spending through improved supervision and intervention programs). 
laying off up to 500 employees, in order to save $\$ 118$ million in fiscal year 2010 , while New York plans to close three minimum security correctional camps and parts of seven more facilities. "All told, at least 22 states have shut facilities, reduced beds, halted expansions, or delayed the opening of new facilities." 109

The biggest budgetary savings, however, lie elsewhere. According to a Vera Institute Report:

Staffing typically accounts for 75 to 80 percent of corrections budgets, so substantial cost reductions can be achieved only when the prison population shrinks enough to shutter a facility-whether a single cellblock or an entire prison. In FY2010, states looking for large cuts have turned to release policies and found that they can identify some groups of people who can be safely released after serving shorter terms behind bars. ${ }^{110}$

Nor are such fiscal considerations the only reason why states are desperately seeking remedies for prison overcrowding. ${ }^{11}$ An earlier Vera Institute report found that such conditions encourage greater violence, illness, and discontent among both prisoners and corrections staff. Overcrowded prisons are notoriously difficult to manage. ${ }^{112}$

\section{The Case of California}

California is the most dramatic example of a state under severe pressure to release prisoners prematurely in response to chronic and extreme overcrowding. The number of criminals incarcerated in California soared during recent decades as voters and lawmakers approved tough penal measures such as the "three-strikes" law. ${ }^{13}$ Costs soared as well, of course, doubling in the last decade in nominal dollars. ${ }^{114}$ Currently, approximately 11 percent of the state budget-roughly $\$ 8$ billion-goes to the penal system, which is more than the state spends on initiatives like higher education. ${ }^{115}$ Writing in 2008, one commentator summarized the situation:

California operates both the largest and most overcrowded correctional system in the nation. "California houses more inmates than France,

109. SCOTT-HAYWARD, supra note 107, at 6-7.

110. Id. at 2 .

111. See Savage, supra note 67.

112. VERA INSTITUTE OF JUSTICE, supra note 80 , at 11-15.

113. Shane Goldmacher, California's Prison Population Falls for the Third Straight Year, L.A. TiMES (Mar. 17, 2010), http://articles.latimes.com/2010/mar/17/local/la-me-prisons $17-2010 \mathrm{mar} 17$.

114. Id.

115. Randall C. Archibold, California, in Financial Crisis, Opens Prison Doors, N.Y. Tıмı:s, Mar. 23, 2010, at Al4. 
Great Britain, Germany, Japan, Singapore, and the Netherlands combined." Further, California has the highest rate of recidivism in the nation, and its inmate suicide rate is twice the national average. The state's prison system is so massive that it is predicted that in five years the state will spend more money on prisons than it does on higher education. California's thirty-three state prisons currently house approximately 173,000 inmates in space designed for half that amount. Every California prison holds substantially more inmates than it was originally designed to hold, with many operating at over 200 percent of capacity. For example, when Avenal State Prison opened in 1987, it was designed to house 2,920 inmates; in 2007, it housed 7,525. California's local county jails are similarly plagued by severe overcrowding. ${ }^{16}$

By 2010, after years of judicial oversight and pressure to reduce its prison population, the state's prisons still held 164,000 inmates, double their intended capacity. ${ }^{117}$

Critics find that conditions in California's local jails are at least as bad as in its prisons. ${ }^{118}$ According to a May 2010 report by the American Civil Liberties Union of Southern California, the Los Angeles County jail system was the largest such system in the United States, housing nearly 20,000 detainees and costing nearly $\$ 1$ billion a year to operate. ${ }^{119}$ The Men's Central Jail housed about 25 percent of the total L.A. jail population, and the prison operated at about twice its official capacity. ${ }^{120}$ The spatial constraints had resulted in increased rates of violence, psychiatric breakdown, and suicide in correctional facilities. ${ }^{121}$ Unsanitary and hazardous living conditions existed within the Men's Central Jail; prisoners were housed in windowless cells and dorms plagued by poor ventilation, plumbing leakages and stoppages, and extreme temperatures. ${ }^{122}$ The space provided per prisoner in the jail fell shockingly short of nationally recognized standards. ${ }^{123}$ Overcrowding was a common theme behind all major problems at the Men's Central Jail, including the culture of violence, a lack of transparency, poor screening and treatment for the mentally disabled, and unsanitary living conditions. $^{124}$

116. David Muradyan, California's Response to the Prison Overcrowding Crisis, 39 McGrorgE: L. Rev. 482, 484-85 (2008), citing Byron Williams, California Prison Crisis Product of Long-Term Neglect, http://www.Huffingtonpost.com/byron-williams/california-prison-crisis-_b_58267.html (July 29, 2007, 02:38 EST) (on file with the McGeorge Law Review).

117. Jess Bravin, California Prisons Frustrate Justices, WAl.I. St. J., Dec. 1, 2010, at A6.

118. Amisican Civit. Libirtilis Union ol Southi:Rn California, ANnual. Riport on CondiTIONS INSIDI: MiEN's ClintRAL. JAII. 2008-2009, (2010), available at http://www.aclu.org/prisonersrights/annual-report-conditions-inside-mens-central-jail-2008-2009.

119. Id. at 1 .

120. Id.

121. Id. at 38.

122. Id. at 2 .

123. Id.

124. Id. 
Not surprisingly, politicians and inmates' lawyers have taken notice. In 2006, Governor Arnold Schwarzenegger declared a "prison overcrowding state of emergency," warning that conditions in the state's thirty-three adult prisons posed a serious risk to inmates and staff. ${ }^{125}$ Nevertheless, the state of California has been fighting to fend off class action civil rights lawsuits regarding prison conditions over the past several years. On June 23, 2007, two lawsuits were filed contending that California's severe and chronic overcrowding had caused unconstitutionally inadequate and dangerous conditions in the prisons, including endemic violence, suicides, and lack of access to health care. The cases, Coleman v. Schwarzenegger and Plata v. Schwarzenegger, were consolidated and referred to a three-judge panel which, on August 4, 2009, ordered the state to submit a plan within forty-five days detailing "a population reduction plan that will in no more than two years reduce the population of [California's adult prisons] to $137.5 \%$ of their combined design capacity," ${ }^{\prime 26}$ or about 40,000 inmates. ${ }^{127}$ The state submitted various inmate population reduction plans, the final version of which was accepted on January 12, 2010.

Shortly thereafter, with the prison population at almost 200 percent of capacity, the California Department of Corrections and Rehabilitation (CDCR) nominally launched a program to reduce the state prison population by 6,500 inmates. This was done primarily by increasing the availability of good-time credits and diverting those guilty of technical parole violations away from prison. ${ }^{128}$ At the same time, the state appealed the court order, and the U.S. Supreme Court granted certiorari to determine whether the three-judge panel indeed had the proper jurisdiction to enter that order. ${ }^{129}$

On November 30, 2010, the Court heard oral argument in the case, now called Brown v. Plata. A number of the justices expressed considerable dissatisfaction and frustration with the state's lack of progress in reducing its

125. Proclamation No. 4278, available at http://gov.ca.gov/news.php?id $=4278$.

126. Coleman v. Schwarzenegger, 922 F. Supp. 2d 882, 1003 (E.D. Cal \& N.D. Cal. 2009).

127. Id.; Plata v. Schwarzenegger, 603 F.3d 1088 (9th Cir. 2010).

128. The CDCR said that it was achieving its reduction in prison populations by strengthening its parole system, and targeting resources more strategically. Low-risk parolees would get less supervision, drug and mental health recovery courts would be expanded, and the parole agent-parolee ratio would be increased, among other measures. Press Release, California Department of Corrections and Rehabilitation, CDCR Implements Public Safety Reforms to Parole Supervision, Expanded Incentive Credits for Inmates (Jan. 21, 2010), available at http://cdertoday.blogspot.com/2010/01/ cdcr-implements-public-safety-reforms.html. Recidivism rates for the CDCR have not yet been released for 2010 , so it is not yet ascertainable what the effect of the new policy may have been in this respect. For the most current and archival information about CDCR recidivism rates see Offender Information Reports, CAL. DEP'T of CORRECTIONS AND REHABILITATION, http://www.cdcr.ca.gov/ Reports_Research/Offender_Information_Services_Branch/Offender_Information_Reports.html (last visited Feb. 15, 2012). The state has previously experienced recidivism rates as high as seventy percent. Archibold, supra note 115. In 2010, 71.3 percent of felon parolees in California were returned to prison. 55.5 percent of paroloees were returned for violating the conditions of their parole, and $\mathbf{1 5 . 8}$ percent of parolees were returned to prison with a new prison term after receiving a court sentence for a new crime. Cal. Dep't of Corrections and Rehabilitation, Rate of Felon Parolees Returned to California Prisons, Calendar Year 20102 (2011).

129. Schwarzenegger v. Plata, 560 U.S. 964 (2010). 
prison census, but seemed reluctant to say which specific measures the state should take to satisfy the constitutional standard, other than spending more money on the problem. ${ }^{130}$ Their reluctance probably reflects the effect of the PLRA, ${ }^{131}$ in which Congress restricted the authority of courts to issue orders specifying in detail how prison officials must operate their systems or otherwise limiting their discretion-unless the courts expressly find that such specifications are the least intrusive remedies that are necessary to cure the constitutional violation. ${ }^{132}$

The Supreme Court issued its decision in Brown v. Plata on May 23, 2011. ${ }^{133}$ The Court upheld the three-judge court's order, ruling that the court-mandated population cap was necessary to remedy the unconstitutional overcrowding. The Court also held that the PLRA authorized the relief ordered by the three-judge court. ${ }^{134}$

Since the three-judge panel's initial order, California has barely succeeded in reducing its prison population. ${ }^{135}$ Initially, the reduction in population was accomplished mostly through transfers to out-of-state private prisons. ${ }^{136}$ As of mid-July 2013, California had not yet taken any steps to reduce the prison population through a general practice of releasing incarcerated prisoners early, nor had such a plan ever been proposed by any of the parties to the litigation. ${ }^{137} \mathrm{~A}$ number of state programs had an initial modest effect on prison population reduction. In 2009, CDCR implemented a new program of good-time credits and changed parole practices. ${ }^{138}$ The CDCR program, required under state legislation passed in October 2009, included several new practices targeted toward reducing the state's prison population. First, the expanded good-time credits program allowed inmates to earn up to six weeks off of their sentence per year by completing certain rehabilitation programs, such as earning a GED, as well as additional credits for completing firefighting training and working in institution firehouses, and for certain offenders,

130. Justice Breyer referred to the photographs of prison conditions as "pretty horrendous." Transcript of Oral Argument at 20, Schwarzenegger v. Plata, 560 U.S. 964 (2010) (No. 09-1233), available at http://www.supremecourt.gov/oral_arguments/argument_transcripts/09-1233.pdf.

131. Supra note 4.

132. The strategy of targeting low-risk prisoners for good-time credits or parole violation diversion will likely have less effect in California than it might elsewhere because approximately one out of five prisoners in the state are serving life sentences, most of which were imposed for violent crimes. Nationwide, only ten percent of prisoners are serving life sentences. Solomon Moore, Number of Life Terms Hits Record, N.Y. TIMES, July 22, 2009 at A24.

133. Brown v. Plata, 131 S. Ct. 1910 (2011).

134. Id. at 1923.

135. Telephone Interview by Talia Kraemer with Rebekah Evenson, Staff Attorney, Prison Law Office (Feb. 4, 2011).

136. Id. See also Marisa Lagos, California to Ship More Prisoners Out of State, San Francisco Chronicle, Nov. 30, 2010.

137. Telephone Interview by Talia Kraemer with Rebekah Evenson, Staff Attorney, Prison Law Office (Feb. 4, 2011). Telephone Interview by Jacob Goldberg with Rebekah Evenson, Staff Attorney, Prison Law Office (July 23, 2013).

138. Id. 
credit was given for time served in county jail since sentencing. ${ }^{139}$ Inmates lost earned credits for criminal misconduct, rules violations, and violence in prison. ${ }^{140}$ Gang members and those convicted of certain violent crimes were not eligible for the credits. ${ }^{141}$

The program also made three changes to California's current parole practices. First, it created a new category of summary parole for certain lowrisk offenders. ${ }^{142}$ Offenders who were released to summary parole are subject to standard parole search and seizure conditions upon release, but not to traditional parole supervision. ${ }^{143}$ Second, it implemented the use of a "parole violation decision making instrument" to guide the choice of appropriate sanctions for parole violators based on the individual's risk of reoffending. ${ }^{144}$ Third, the program established and expanded drug and mental health reentry courts to divert parole violators away from prison and into highly structured treatment programs. ${ }^{145}$ Under California's old parole practices, 70,000 parolees were reentering California prisons each year for technical violations without a court sentence for a new crime. ${ }^{146}$ The combination of parole initiatives may be expected to have some meaningful impact on the California prison population. In addition to the good-time credit and parole changes, the new California law raises the minimum monetary threshold for certain grand theft crimes. ${ }^{147}$ This change gives state prosecutors increased discretion to charge certain offenses as misdemeanors, rather than felonies, which would result in jail rather than prison time for the offender and further reduce the prison population. ${ }^{148}$

Since the fall of 2011, the core of California's strategy to reduce state prisoner overcrowding has been the 2011 Public Safety Realignment Plan

139. Press Release, California Department of Corrections and Rehabilitation, CDCR Implements Public Safety Reforms to Parole Supervision, Expanded Incentive Credits for Inmates (Jan. 21, 2010), available at http://cdcrtoday.blogspot.com/2010/01/cder-implements-public-safety-reforms. html. The extension of good-time credits is, in a sense, its own form of "early release." However, all states have good-time credit programs, and until recently, California has had one of the more restrictive good-time credit programs in the country. These changes thus bring California more in line with standard practice. Telephone Interview by Talia Kraemer with Rebekah Evenson, Staff Attorney, Prison Law Office (Feb. 4, 2011).

140. Press Release, California Department of Corrections and Rehabilitation, supra note 139.

141. Telephone Interview by Talia Kraemer with Rebekah Evenson, Staff Attorney, Prison Law Office (Feb. 4, 2011).

142. Prior to these recent changes, California was unusual in that all prisoners, regardless of risk designation, were released directly into parole supervision for a minimum of three years. $I d$.

143. Press Release, California Department of Corrections and Rehabilitation, supra note 139.

144. Id.

145. Id.

146. Dep't of Corrections and Rehabilitation OHFender InFormation Sizvices Branch, Rate of Felon Parolees Returned to California Prisons, Calindinar Yisar 2009, at 1 (2010), available at http://www.cdcr.ca.gov/Reports_Research/Offender_Information_Services_Branch/ Annual/PVRET2/PVRET2d2009.pdf.

147. Supra note 141

148. Id. 
("Realignment"), which began on October 1, 2011. ${ }^{149}$ Under Realignment, responsibility for incarcerating and supervising the parole of low-level offenders has been transferred from the state to the counties. ${ }^{150}$ Nonserious, ${ }^{151}$ non-violent ${ }^{152}$ offenders who have not been convicted of registerable sex crimes will serve their sentences in county jails instead of in state prisons for terms of up to three years. ${ }^{153}$ There are sixty-three crimes that have been designated exceptions to this general rule. ${ }^{154}$ For these crimes, offenders must serve time in state prison even though the crimes are not designated as serious or violent crimes under the California Penal Code. ${ }^{155}$

Under Realignment, counties are also responsible for supervising parole of inmates released from jail or prison if the inmate's most recent offense was non-serious and non-violent. ${ }^{156}$ The state retains parole supervision over inmates who are paroled from life sentences, offenders whose current offense was a serious or violent offense, high-risk sex offenders, and offenders with mental health disorders. ${ }^{157}$ For all parolees, any time served for revocation of parole must be served in county jail instead of in state prison, with the sole exception of life-term offenders, who may be returned to state prison. ${ }^{158}$

In addition to these measures, the remaining population reduction is to be achieved through a combination of initiatives, including (1) increasing capacity by creating new prison and jail beds; ${ }^{159}$ (2) releasing selected inmates early under medical parole; ${ }^{160}$ and (3) an alternative custody pro-

149. See generally 2011 Public Safety Realignment, CA.Gov, http://www.cdcr.ca.gov/realignment (last visited Dec. 18, 2011); CAL. DI:P'T OF CORRICCTIONS AND REHABILITATION, REALIGNMENT REPORT (Dec. 2013), available at http://www.cdcr.ca.gov/Adult_Research_Branch/Research_Documents/ Realignment_1_Year_Report_12-23-13.pdf.

150. Defendants' Report in Response to January 12, 2010 Order at 6, Plata v. Brown, No. 3:01-cv01351 (E.D. Cal \& N.D. Cal., June 7, 2011).

151. "Serious" offenses are defined in Calıfornia Plinal. CoDl: $\$ 1192.7$ (c).

152. "Violent" offenses are defined in CAI.liornia PIinal. CoDI $\$ 667.5(\mathrm{c})$.

153. Defendant's Report, supra, note 150, at 6-7.

154. Cal. Diep't of Corrections ani) Rihabilitation, Final Crime Exclusion list, available at www.cdcr.ca.gov/realignment/docs/Final-Crime-Exclusion-List.pdf (last visited Dec. 18, 2011). Although the website says there are 59 exceptions, the official list contains 63 .

155. AB 109 Final Crime Exclusion List, CA.Gov, http://www.cdcr.ca.gov/realignment/AB-109final-crime-exclusion-list.html (last visited Dec. 18, 2011).

156. Post-Release (County-Level) Community Supervision, CA.gov, http:/www.cdcr.ca.gov/ realignment/Post-Release-Community-Supervision.html (last visited Dec. 18, 2011 ).

157. Id.

158. Parole Revocations, CA.Gov, http://www.cdcr.ca.gov/realignment/Parole-Revocations.html (last visited Dec. 18, 2011)

159. Press Release, California Department of Corrections and Rehabilitation, CDCR and Madera County Officials Break Ground on \$34 Million, 144-Bed Expansion of Jail, (July 7, 2011), available at http://cdcrtoday.blogspot.com/2011/07/cdcr-and-madera-county-officials-break.html. Under AB 900 , the state expects to add up to 53,000 new prison and jail beds through a combination of facility construction and conversion of existing facilities. $I$ d.

160. Marisa Lagos, Calif. convict wins state's first medical parole: 3rd strike, in 2007, was robbery of elderly couple, S.F. CHRON., June 16, 2011, http://articles.sfgate.com/2011-06-16/bay-area/ 29664067_I_medical-condition-medical-parole-craig-lemke. Under a new law, state prison inmates may be released early if the state parole board determines that the inmates (1) are "permanently medically incapacitated with a medical condition" that makes them "unable to perform activities of basic daily living" and (2) do not pose a threat to public safety. Id. 
gram that seeks to reunite low-level offenders with their families. ${ }^{161}$

In all, though, these programs have had a limited effect. By 2012, the state had practically abandoned any attempt to meet the court order. In the spring of 2012, Governor Jerry Brown's administration released and the legislature adopted a "Blueprint" to "save billions of dollars, end federal court oversight, and improve the prison system." 162 The Blueprint acknowledged that Realignment alone would not bring the state into compliance with the court order. ${ }^{163}$

Rather than proposing further reduction measures, however, the Blueprint suggested that appropriate steps had been taken and, by planning to bring back prisoners housed out of state, actually proposed to increase the state's prison population. ${ }^{164}$ In a November 2012 court filing, the state acknowledged that it would not meet the upcoming benchmark and requested a modification of the order. ${ }^{165}$ The three federal judge court which had ordered the prison reduction noted, "the Blueprint is not a plan for compliance; it is a plan for noncompliance." "166

True to its Blueprint, California has not supplemented Realignment with other policies intended to reduce its prison population. Instead, the state has taken a series of actions to avoid the court order or openly defy it. In January 2013, the Governor declared that the state of emergency regarding prison overpopulation had ceased, terminated his emergency powers, and ended a program to house inmates out of state. ${ }^{167}$ On January 7 and, again, on May 2,

161. Under the Program, non-serious, non-violent, non-sex offenders may qualify to serve part of their sentences in a residential home, non-profit residential drug-treatment program, or a transitionalcare facility. Currently, the program is only available to female inmates, although the state may later make it available to male inmates who are primary caregivers. To be eligible, female inmates must have one year or less remaining in their state prison sentences, and they must volunteer for the program. Inmates may be excluded from the program if they (1) currently or in the past committed a serious or violent felony, (2) currently or in the past committed a sex offense, (3) escaped from custody within the past 10 years, (4) are subject to an active restraining order, (5) committed certain in-prison misconduct, (6) are affiliated with a gang, or (7) have a felony or ICE hold. The California Department of Corrections and Rehabilitation (CDCR) retains responsibility for all inmates in the program. Parole agents are responsible for the inmates' supervision and case management, but CDCR does not staff the residences where inmates are housed or pay for their housing. CDCR estimates that $45 \%$ of female inmates will potentially be eligible for the program, though the percentage of inmates approved for the program will be lower. CDCR predicts that the program will save the state $\$ 6$ million in the next year. Cal. Dep't of Corrections and Rehabilitation, Fact Sheet: Alternative Custody Program (Sept. 12, 2011), available at www.cdcr.ca.gov/Adult_Operations/FOPS/docs/ACP-FactSheet-Final.pdf.

162. State of California, The Future of California Corrections: A Blueprint to Save Billions of Dollars, End Federal Court Oversight, and Improve the Prison System 1 (2012), available at http://www.cdcr.ca.gov/2012plan/docs/plan/complete.pdf.

163. Id. at 10.

164. Id. at 8,32

165. Defendants' November 2012 Status Report \& Motion to Modify June 30, 2011 Order Requiring Interim Reports at 3, Coleman v. Brown, No. 2:90-cv-00520-LKK (E.D. \& N.D. Cal. Nov. 15, 2012), ECF No. 4259.

166. Opinion \& Order Denying Defendants' Motion to Vacate or Modify Population Reduction Order at 63, Coleman v. Brown, No. 2:90-cv-00520-LKK (E.D. \& N.D. Cal. April 11, 2013), ECF No. 4541 .

167. Edmund G. Brown, Jr., A Proclamation by the Governor of the State of California (2013), available at http://gov.ca.gov/news.php?id =17886. 
California filed motions to modify or vacate the court's population reduction holding. ${ }^{168}$ Both motions were denied. ${ }^{169}$ The state, then, filed an appeal to the Supreme Court to vacate the population reduction order. ${ }^{170}$ On October 15, 2013, in a one sentence summary disposition, the Court denied the appeal. ${ }^{171}$ California must still comply with the population reduction order.

In the midst of litigation, the state has made a number of proposals specifically involving the criminal immigrant population. ${ }^{172}$ First, it proposed that the Governor review the cases of deportable inmates and identify some as eligible for sentence commutation, which would allow for the prisoner's immediate release into federal custody and subsequent deportation. ${ }^{173}$ The proposal was never seriously considered or adopted, however. ${ }^{174}$ Second, the State relied on changed parole practices for deported criminals that it already implemented. ${ }^{175}$ Prior to 2009 , once a criminal immigrant was discharged from prison and deported, California still maintained the individual on a parole agent's caseload, though without active supervision. ${ }^{176}$ If the deported parolee returned to California illegally, California would return the parolee to a California prison for a parole violation. ${ }^{177}$ Under the new policy, California discharges criminal immigrants from parole once they've been deported and leaves any charges for illegal reentry to the federal government. ${ }^{178}$ California estimates that this new policy will result in a reduction in the average daily prison population of 1,000 inmates per year. ${ }^{179}$

The plaintiffs in the litigation have also unsuccessfully put forward

168. Defendants' Response to April 11, 2013 Order Requiring List of Proposed Population Measures; Court-Ordered Plan at 2-5, Coleman v. Brown, No. 2:90-cv-00520-LKK (E.D. \& N.D. Cal. May 2, 2013), ECF No. 4572. See also Vauhini Vara, California Outlines Cuts to Prison Population, WaLL ST. J. (May 3, 2013) http://online.wsj.com/article/SB 100014241278873245820045784612034 01228188.html.

169. Opinion \& Order Requiring Defendants to Implement Amended Plan at 1-3, Coleman v. Brown, No. 2:90-cv-00520-LKK (E.D. \& N.D. Cal. June 20, 2013), ECF No. 4662.

170. Defendants' Motion to Stay Three-Judge Court's June 20, 2013 Order Requiring Defendants to Implement Amended Plan Pending Appeal at 4-5, Coleman v. Brown, No. 2:90-cv-00520-LKK (E.D. \& N.D. Cal. June 28, 2013), ECF No. 4673.

171. SUPREME COURT OF THE UNITED STATES, OCTOBER 15, 2013 Order LIST 1 (2013), available at http://www.supremecourt.gov/orders/courtorders/101513zor_4g25.pdf.

172. Interview by Jacob Goldberg with Rebekah Evenson, Staff Attorney, Prison Law Center (July 23, 2013).

173. Exhibit A State Defendants' November 12, 2009 Response to the Three-Judge Court's October 21, 2009 Order to Reduce Prison Population to 137.5\% of Design Capacity at 7-8, Coleman v. Schwarzenegger, No. 2:90-cv-00520-LKK (E.D. \& N.D. Cal. Nov. 12, 2009), ECF No. 3726-1. Sentence commutation for criminal immigrants has been used by Governor David Paterson in New York for opposite ends: Governor Paterson recently pardoned twenty-four immigrants in order to avoid the immigrants' deportations, not facilitate them. See 24 Immigrants Pardoned by Governor, N.Y. Times (Dec. 25, 2010) http://www.nytimes.com/2010/12/25/nyregion/25pardon.html?_r=0.

174. See supra note 172.

175. Supra note 170 at 10 .

176. Id.

177. Id.

178. Press Release, Cal. Dept. of Corr. and Rehab,, CDCR to Discharge Deported Criminal Aliens to Federal Authorities (Mar. 2, 2009), available at http://www.cdcr.ca.gov/News/Press_ Release_Archive/2009_Press_Releases/Mar_02.html.

179. Id. 
proposals relating to the immigrant criminal population, ${ }^{180}$ specifically that the state should transfer all prisoners with ICE holds (i.e. those transferred to ICE custody on their release date) to ICE when the prisoner is within 6 months of her release date, ${ }^{181}$ which the plaintiffs claim would reduce California's prison population by 1,298 to 1,038 inmates. ${ }^{182}$

California responded to and rejected these suggestions on both policy and legal grounds. First, the state claimed that granting early release to deportable inmates would pose public safety issues: inmates would not necessarily be deported and many of those deported might return. ${ }^{183}$ According to the state, "Plaintiffs' proposal could cause numerous serious or violent offenders being released back into California when federal immigration officials decline to deport them, or when they return to California after having been deported."

Second, the state claimed that it did not have legal authority to order early release of non-citizen inmates, even if released to ICE custody. The state cited three state law provisions. California Constitution, Article 1, Section $28(f)(5)$ provides that no inmate may be released prior to the completion of his or her sentence in order to alleviate overcrowding. ${ }^{185}$ California Penal Code section 2901 prohibits CDCR wardens from releasing inmates until their sentences are complete. ${ }^{186}$ California Constitution Article 5, Section 8 prohibits the Governor from commuting the sentences of twice-convicted felons absent a vote of four judges of the California Supreme Court. ${ }^{187}$

Finally, even if the state were to acquire legal authority to implement the measure, California claimed that its ability to work with ICE might undermine the proposal. The state would need to negotiate an agreement with ICE to take the prisoners six months before their sentences had expired. Given the federal budget sequester, the state speculated that ICE might not be able to hold these inmates and might not agree to the policy. ${ }^{188}$ If negotiations were successful, the state estimated, it would take four to six months to begin

180. JFA Institute, James Austin PhD., http://www.jfa-associates.com/austin.html (Accessed July 6, 2013).

181. Declaration of James Austin in Support of Plaintiffs' Statement in Response to October 11, 2012, Order Regarding Population Reduction at 9, Coleman v. Brown, No. 2:90-cv-00520-LKK (E.D. \& N.D. Cal. Jan. 7, 2013), ECF No. 4283-1.

182. Id. at 11 .

183. Defendants' Response to April 11, 2013 Order, supra note 168, at 38.

184. Id.

185. Cal. Const. art. I, $\$ 28(f)(5)$ ("Sentences that are individually imposed upon convicted criminal wrongdoers based upon the facts and circumstances surrounding their cases shall be carried out in compliance with the courts' sentencing orders, and shall not be substantially diminished by early release policies intended to alleviate overcrowding in custodial facilities.").

186. Cal. Penal Code $\$ 2901$; supra note 13, at 38 .

187. Cal. Const. Art. V, \$ 8(a); supra note 13, at 27 (“The Governor may not grant a pardon or commutation to a person twice convicted of a felony except on recommendation of the Supreme Court, 4 justices concurring."); Defendants' Response to April 11, 2013 Order, supra note 168, at 27.

188. Defendants' Response to April 11, 2013 Order, supra note 168, at 27-28. 
implementation in order to identify prisoners for release and resolve other logistical problems. However, if ICE refused to agree to hold the inmates for at least six months, the state reasoned that its constitutional and penal code provisions would make such a program completely unworkable. ${ }^{189}$

Despite rejecting all of the immigration-related proposals, the state has modestly reduced its prison population. Since October 2011, the state's prison population has decreased by over 34,000 inmates. ${ }^{190}$ The number of parolees has also declined, from an all-time high of 125,105 on August 15, 2007 to a current total 47,053 parolees. ${ }^{191}$ On December 28,2011 , the state met its first court-ordered reduction target: the population was at $166.8 \%$ of design capacity, just under the court-ordered target of $167 \%$, but several individual prisons remained egregiously overcrowded. For example, Mule Creek State Prison was at $202.9 \%$ of design capacity, and Avenal State Prison was at $195.9 \% .^{192}$

The moderately successful population reduction at the state level has been possible because Realignment simply shifted some of the overcrowding problem to county jails. The initial influx of prisoners to the counties has been higher than originally projected in part because many defense attorneys delayed sentencing until after Realignment began so that their clients would serve time in jail instead of in state prison. ${ }^{193}$ For example, Orange County has received twice as many new inmates as originally projected, making it likely that the county will reach its jail capacity by May $2012 .{ }^{194}$ Although the state has allocated funds to the counties for Realignment, many counties say these funds are not sufficient. ${ }^{195}$ Moreover, several counties are themselves under court order from separate lawsuits forbidding overcrowding in those counties' jails. ${ }^{196}$

Counties have responded to the influx of inmates with a variety of measures. Riverside County passed an ordinance that will charge inmates

189. Id. at 28 .

190. Court-Ordered Targets for CDCR Inmate Population Reduction, http://www.cdcr.ca.gov/ realignment/3jp-chart.html; The Cornerstone of California's Solution to Reduce Overcrowding, Costs, and Recidivism, CA.ciov, http://www.cdcr.ca.gov/realignment (last visited February 10, 2014) (Weekly Population Figures chart).

191. Id.

192. Defendants' January 2012 Status Report in Response to June 30, 2011 Order at 6, Coleman v. Brown, No. 2:90-cv-00520-LKK (E.D. \& N.D. Cal. Jan. 6, 2012), ECF No. 4141.

193. Katy Sweeny, Butle County Jail Crowded; Prisoner Realignment Shifts 110 to County Lockup, ChICO ENTIRI'RISE-RECORD (Dec. 12, 2011) http://www.chicoer.com/ci_19528220; Richard Winton \& Andrew Blankstein, County Jails Filling Faster Than Feared; Sheriffs Scramble To Handle Unexpectedly Large Numbers of Inmates Diverted from California Prisons, L.A. TıM:s, Nov. 16, 2011 , at Al.

194. Winton \& Blankstein, supra note 193.

195. Steven Harmon, Brown Hails Public-Safety Handoff to Locals, ContRa Costa TIMEs (Sept. 29, 2011) http://www.contracostatimes.com/ci_19006574. The state will provide counties with $\$ 400$ million this fiscal year, $\$ 850$ million the next fiscal year, and $\$ 1$ billion each year after that. Id.

196. See, e.g., Sweeny, supra note 193; Winton \& Blankstein, supra note 193. 
$\$ 142.42$ nightly for their stays in the county's jails. ${ }^{197}$ While many inmates will not be able to pay, the county estimates that about $25 \%$ of inmates will be able to contribute some amount. ${ }^{198}$ Riverside County expected to reach its jails' capacity by the end of $2011 .{ }^{199}$ Fresno County is no longer incarcerating parolees for parole violations, in order to avoid overcrowding. ${ }^{200}$ In Orange County, jail inmates sleep on the floor until new beds are made available. ${ }^{201}$

Other counties have begun releasing jail inmates early. San Bernardino County began releasing 150 inmates on December 9, 2011 to ease overcrowding. ${ }^{202}$ Most of the inmates released by the county were to be parole violators or inmates convicted of nonviolent crimes. ${ }^{203}$ Under the county's plan, inmates must have served at least half of their sentences and have less than thirty days remaining in order to be eligible for early release. ${ }^{204}$ In Kern County, the sheriff's department released fifty parole violators early due to a lack of bed space, and as of November 2011, Los Angeles County was considering releasing inmates awaiting trial and monitoring them with electronic monitors instead. ${ }^{205}$ Thus, while the state has repeatedly affirmed that it will not release prisoners from state prisons early to comply with the Brown v. Plata order, ${ }^{206}$ the state has indirectly caused early releases by diverting inmates to county jails that are ill-equipped to house them. ${ }^{207}$

The conditions in California's prisons and its response have had negative effects both inside and outside of the prison system. In 2013, in part due to overcrowding, California experienced massive prison unrest. In July 2013, 30,000 California prisoners began a hunger strike to protest prison conditions and the state's use of solitary confinement. This was the third and longest prisoner hunger strike in two years. ${ }^{208}$ Reallignment may also have decreased public safety. After a prolonged period of decline, California's crime rates modestly increased in 2011 and 2012. One study by the Public Policy

197. Jennifer Medina, In California, a Plan to Charge Inmates for Their Stay, N.Y. TIMEs (Dec. 11, 2011) http://www.nytimes.com/2011/12/12/us/in-riverside-california-a-plan-to-chargeinmates.html emc $=$ tnt\&tntemail $1=y$.

198. Id.

199. Kate McGinty, Sheriff: Jails Will Reach Capacity by Year's End, Desert Sun, Oct. 25, 2011.

200. Sweeny, supra note 193.

201. Id.

202. Richard Winton \& Andrew Blankstein, County Jails Struggle with Prisoner Influx; Overcrowding Shifts from State Prisons, Forcing Early Release of Some Inmates, L.A. TIMES, Dec. 10, 2011 , at AAl.

203. Id.

204. Id.

205. Winton \& Blankstein, supra note 144.

206. See, e.g., 2011 Public Safety Realignment, CA.gov, http://www.cdcr.ca.gov/realignment (last visited Feb. 15, 2012).

207. E.g., Vauhini Vara \& Bobby White, County Jails Prepare for Exira Guests, WALl. ST. J., Aug. 10, 2011, at A4 (discussing chaotic preparations on the State and County level and noting a report by the Legislative Analyst's Office that warns that the Supreme Court mandate may not be met).

208. Bob Egelko, California Prison Inmates End Hunger Strike, S.F. Gate (Sept. 5, 2013) http:/www.sfgate.com/crime/article/California-prison-inmates-end-hunger-strike-4789436.php. 
Institute of California suggests that realignment has contributed to an increase in property crimes. ${ }^{209}$

\section{The Legislative History of the Imprisonment-Before- DEPORTATION RULE}

Prison over-crowding, then, creates enormous legal, political, fiscal, and management incentives to reduce the teeming prison population. In this situation, one might predict that the federal government would try to reduce this population, and thereby relieve some of the pressures for premature release, by focusing its policy attention on a large subset of inmates-those immigrant criminals who can be deported immediately (more or less) and whom the government expects to deport eventually anyway. Were it to deport them now rather than later, the government would in a single stroke gain several important policy advantages. First, it would reduce-and perhaps (depending on the numbers) end-the prison over-crowding. Second, it would eliminate the substantial time and cost of incarcerating and maintaining immigrant criminals in prison. Third, by hastening the criminals' return to their native countries, it would accelerate what is likely, even under the best of circumstances, to be a difficult and protracted process of re-integration into those societies.

Why, despite these large potential benefits of pre-incarceration removals, has the government not taken this straightforward course? The reason lies in an almost century-old provision of the immigration statute, INA Section 241(a)(4), which provides that, with exceptions for certain nonviolent offenders discussed at the end of this Part, the government "may not remove an alien who is sentenced to imprisonment until the alien is released from imprisonment. Parole, supervised release, probation, or possibility of arrest or further imprisonment is not a reason to defer removal."210

This Part analyzes the history and rationale for this "imprisonment-beforedeportation" rule. Three points emerge from the historical analysis of the rule. First, it was based on a set of legislative facts and rationales that no longer make as much sense as they originally did. In particular, it did not take account of the much more recent problem of prison over-crowding and the changed legal, fiscal, and political contexts that this problem has created. Second, the only exceptions to the rule, enacted in 1996, are limited (they apply only to certain nonviolent offenders) and have been used much less than they could and should be used. Third, Congress has never focused on this provision, much less reconsidered these rationales, with the exception of a limited, unsuccessful effort in 1993.

209. Magnus loftstrom \& Steven Raphael, Pub. Policy inst. of Cal., Public Safety ReALIGNMENT AND CRIME RATES IN CALIFORNIA 2 (2013), available at http://www.ppic.org/content/pubs/ rb/RB_1213MLRB.pdf.

210. Immigration and Nationality Act (INA) $\$ 241$ (a)(4)(A), 8 U.S.C. $\$ 1231$ (a)(4)(A) (2014). 


\section{A. Early Congressional Debates About the Deportation of Post-Arrival Immigrant Criminals}

Prior to the Act of 1917, discussed below, non-citizens who had been convicted of crimes in their home countries were deportable, ${ }^{211}$ but no provision authorized the deportation of those who entered the United States legally and committed crimes only thereafter while inside the country. The question analyzed in this paper-whether immigrant criminals should serve out their sentences in United States prisons before being deported-was not considered until Congress entered into the much broader debate over whether non-citizens who committed crimes after their arrival here should be deported at all, a debate that culminated in the 1917 law and its "imprisonmentbefore-deportation" provision.

Since 1890, Congress had debated the major contours and philosophies of immigration law and policy. Congressional debate about immigration focused on such broad topics as, the "restriction [of immigration] as a principle of policy, numerical restriction, the restriction of various subgroups, and ... the national origins quota system." ${ }^{212}$ In 1907, Congress established a commission to investigate the then-current state of immigration to the United States and to make policy proposals. ${ }^{213}$ Among the topics studied by this "Dillingham Commission" (as it came to be known) was immigrant criminality. The Commission's report concluded that it was "inexcusable" that Congress had failed to adopt legislation providing for the deportation of an immigrant who comes to the United States and, within a certain period of time after arrival, commits a crime. ${ }^{214}$ Canada and the United Kingdom, it noted, had enacted such laws; the United States should follow suit. ${ }^{215}$ The commission, also finding that the nation was oversupplied with unskilled labor, urged that immigration restrictions be imposed to ameliorate this condition, and proposed to exclude "those who, by reason of their personal

211. Immigration Act of 1907, ch. $1134, \S 21,34$ Stat. 898, 905 (1907) (amended 1917).

212. Cheryl Shanks, Immigration and the Politics ol: American Sovereignty, 1890-1990, at 37 (2001).

213. Supra note 211,34 Stat. at 909.

214. S. Doc. No. 61-783, at 26 (1911) ("The other serious, and in the opinion of the Commission inexcusable, defect is the fact that aliens admitted to this country, unless it appears that such admission was in violation of law, may pursue a criminal career without danger of deportation. To deport an alien of any class is entirely within the rights of any government, and provision should be made for ridding the United States of aliens who, within a relatively short time after arrival, become criminals. It seems entirely reasonable and just that this country should not harbor dangerous criminals of another country, especially when their residence in the United States has been so brief that their tendency to crime can not be attributed to conditions arising subsequent to their entry into this country.").

215. Id. ("Under the Canadian immigration law aliens who become a charge upon the public, by reason of crime or any other cause, within three years after their arrival may be, and in considerable numbers are, deported to the countries whence they came. Under the British aliens' act the right to deport criminals is exercised, and the Commission emphatically believes that the same principle should be applied in the United States. It is not believed that the practice of deportation should be sufficiently extended to include minor offenses, nor that the period of time within which deportation could be made should be longer than the period required for naturalization."). 
qualities or habits, would least readily be assimilated or would make the least desirable citizens."216

A passionate decade-long national debate ensued over whether and how best to exclude and deport classes of immigrants, and how to deport postarrival criminals in particular. Most of the congressional debate focused on other issues such as the exclusion of Hindus, ${ }^{217}$ "persons of constitutional psychopathic inferiority,"218 anarchists and other radicals, ${ }^{219}$ and the merits of literacy requirements. ${ }^{220}$ The subtler points of proposed laws received less attention.

The first proposal to authorize the deportation of post-arrival criminals appeared in a bill that came to the House floor on March 2, 1908, and included a provision that such criminals would be deported only at the end of their prison sentences. ${ }^{221}$ Subsequent debate on the bill focused almost entirely on whether deporting post-arrival criminal immigrants was fair and constitutional; the "imprisonment-before-deportation" provision was alluded to but not discussed directly. The notion was expressed that the criminals should have an opportunity to gain a pardon that would vitiate the basis for deportation, and that this possibility implied the need to imprison them here. $^{222}$ One member, Representative Driscoll, did suggest that imprisonment in the United States might cause an unnecessary expense. If the possibility of deportation were considered at the sentencing stage, Driscoll thought, the criminal might be given a shorter sentence in order to hasten deportation. ${ }^{223}$ This suggestion, however, was not pursued. The debate over whether to deport post-arrival criminals at all resumed, and the bill providing for such deportation was ultimately rejected.

In 1910, the full House took up another bill proposing the deportation of post-arrival criminal immigrants. ${ }^{224}$ Again, the debate did not discuss the

216. S. Doc. No. 783 , at 39 (1911).

217. See Hindu Immigration: Hearing Before the Comm. On Immigration, 63d Cong. (1913), H.R. 9044 63d Cong. (1913).

218. H.R. RI:P. No. 64-95, at 2 (1916).

219. See generally id.

220. See id. at 4-6.

221. 42 Con(i. R1:C. 2752 (1908).

222. Id. at 2753 (1908) ("Mr. Sulzer: Suppose a governor shall pardon a man. Mr Bennet of New York: Then the law would not act on him. Mr. Sulzer: He would be restored to all his rights, and hence could not be sent back. Mr. Bennet of New York: The pardon wipes out the conviction. This law only acts at the expiration of his sentence. Similarly it would not act on a man on whom sentence was suspended."). It is not clear why Bennet assumed that the rationale relating to a pardon would also apply to a suspended sentence, and in fact the Act of 1917, which first authorized the deportation of post-arrival criminals, created an exception for pardons but not for suspended sentences. See infra at 234 .

223. 42 Cong. Rec. 2754 (1908) ("Mr. Driscoll: Does not the gentleman think that the courts would be apt to consider the fact that he would be deported after the expiration of his imprisonment in imposing a sentence, and does not the gentleman think really that some courts might make it very short in order to get rid of him? I do not know but it might be as well to make the sentence very short and avoid the expense.").

224. 45 CONG. REC. 1565 (1910). 
"imprisonment-before-deportation" provision, ${ }^{225}$ and again the bill was rejected. Congressional debates in the following years continued to include a vocal minority opposing any deportation of post-arrival criminals. The majority who favored deportation in at least some such cases used the "imprisonment-before-deportation" idea as a way to garner the support of this group.

This tactic can be seen in excerpts from a hearing before the House Committee on Immigration and Naturalization, on March 11, 1916, in which Mr. Arthur Woods, the Police Commissioner of New York City, testified about H.R. 10384, the bill that would eventually insert the "imprisonmentbefore-deportation" requirement. ${ }^{226}$ Chairman John L. Burnett cited the committee's historical concerns about how to handle the cases of immigrants who had lived with clean records in the United States for extended periods of time and only then committed crimes:

We have had that question up a good many times before this committee and we have always taken the view that to the man who comes here and behaves himself right and then commits a crime afterwards the same hard rule ought not to be applied as to the felon who comes here as a felon. 227

Representative Jacob E. Meeker raised the very question that we are examining here, responding to Chairman Burnett:

[I]f he is not our citizen, why is it that we should bear the burden of keeping him here, either in prison or out, if he is not our citizen? ${ }^{228}$

Chairman Burnett answered:

225. H.R. REP No. 61-404 (1910) (Laying out opinions of the majority and the minority of the Committee on Immigration and Naturalization with respect to the deportation of post-arrival criminal aliens, but making no mention of the policy of having them serve out their prison sentences in this country before being deported).

226. Restriction of Immigration: Hearings Before the Comm. on Immigration and Naturalization, 64th Cong. (1916) [hereinafter Restriction of Immigration] (statement of Hon. Arthur Woods, Police Commissioner of New York City).

227. Id. at 12 (emphasis added). The Page Act of 1875 had barred the entry of certain convicts and prostitutes. See Page Act of 1875, ch. 141, 18 Stat. 477 (repealed 1974). "[1]t shall be unlawful for aliens of the following classes to immigrate to the United States[:] persons who are undergoing a sentence for conviction in their own country of felonious crimes other than political or growing out of or the result of such political offenses, or whose sentence has been remitted on condition of their emigration, and women 'imported for the purposes of prostitution." $I d$. at 477 . Responding to states' lobbying for greater federal immigration enforcement and exclusions of certain classes of immigrants, Congress passed the first comprehensive federal immigration law, the Immigration Act of 1882 , which mandated the exclusion and return of all "foreign convicts" and authorized the Secretary of the Treasury to regulate such returns. Immigration Act of 1882, ch. 376, 22 Stat. 214. "[A]ll foreign convicts except those convicted of political offenses, upon arrival, shall be sent back to the nations to which they belong and from whence they came." Id. at 214.

228. Restriction of Immigration, supra note 226, at 13 (statement of Hon. Arthur Woods, Police Commissioner of New York City). 
Well, because we have invited him to our home. He is our guest; he is under our rooftree, and he came in with a clear record and maintained his clear record up to the day of his conviction. ${ }^{229}$

Representative Riley J. Wilson had concerns similar to those of Chairman Burnett:

[T] he man who may come here with a good record, with good purposes and good intentions, and makes good when he arrives here, owing to the fact that our atmosphere is not so perfect as it might be and his associates might not be of the best, might not be entirely responsible for the commission of a crime. I feel as if he might be our criminal, and it might not be just fair to deport him. ${ }^{230}$

Representative Adolph J. Sabath also echoed Chairman Burnett's sentiments:

A great many people who have been here a great many years cannot due to unfortunate conditions that exist, become citizens. Meanwhile they might have been married; they might have an American wife, a woman who has been born here, and they might have two or three children. Now, what would you do with the children and what would you do with the wife? ? $^{31}$

Police Commissioner Woods wanted to prioritize security above all else and to apply rules strictly:

The rule is that if we get a man in this country who has not become a citizen, who knocks down people in the street, who murders or who attempts to murder people, who burglarizes our houses with blackjack and revolver, who attacks our women in the city, those people should not be here, and we should not be mawkish, sentimental, and weak because we are afraid of doing injustice in one case. ${ }^{232}$

Despite his predispositions, however, Police Commissioner Woods eventually agreed with some other committee members that a law dealing with this class of criminal immigrants must address concerns such as those of Chairman Burnett and Representative Sabath through some exceptionmaking mechanism. Imprisoning criminal immigrants before their deportation seemed to be one means by which such concerns could be reconciled with Police Commissioner Woods' emphasis on security: when Chairman Burnett asked, "[b]ut are they not better provided for in Sing Sing than if they are sent back?," Police Commissioner Woods replied, "[p]ut them in Sing Sing first. We have about 600 there now."233

229. Id.

230. Id. at 15 .

231. Id. at 13-14.

232. Id. at 14 .

233. Id. 


\section{B. The Imprisonment-Before-Deportation Rule in the 1917, 1929, and 1952 Acts}

It was in the Immigration Act of February 5, 1917 that the current "imprisonment-before-deportation" rule first appeared, albeit coupled with two anti-deportation protections: for pardoned criminals, and for judicial recommendations against deportation (subsequently known as "JRAD"). Section 19 of that Act read in relevant part:

Provided further, That the provision of this section respecting the deportation of aliens convicted of a crime involving moral turpitude shall not apply to one who has been pardoned, nor shall such deportation be made or directed if the court, or judge thereof, sentencing such alien for such crime shall, at the time of imposing judgment or passing sentence or within thirty days thereafter, due notice having first been given to representatives of the State, make a recommendation to the Secretary of Labor that such alien shall not be deported in pursuance of this Act; nor shall any alien convicted as aforesaid be deported until after the termination of his imprisonment. ${ }^{234}$

The fact that these immigrants would be imprisoned in the United States until their deportations, coupled with the JRAD exception, would provide an opportunity for this judicial relief "at any time before deportation"235 - a concession to lawmakers who opposed the power to deport post-arrival criminals at all. Though this "any time" amendment was eventually rejected in favor of a shorter window for JRAD, the final version of the JRAD provision also relied upon the fact that post-arrival criminals would be imprisoned here; the 1917 Act gave the sentencing judge up to thirty days after the time of sentencing to recommend that the immigrant convicted of a crime of moral turpitude not be deported. ${ }^{236}$ It could be said, then, that one of the purposes served by having criminal aliens serve out their prison sentences in this country was to permit the implementation of an exception-making mechanism, the JRAD, which was itself a bargaining chip in negotiations over whether to deport non-citizen criminals at all.

For purposes of my argument against imprisonment-before-deportation, it is significant that in contrast to the debate in 1917, few if any members of Congress today question the propriety, in principle, of classifying immigrants who commit crimes of moral turpitude (or some other criterion of severity) after arrival as deportable, as they have been since 1917. Indeed, this long-standing moral consensus persists despite the fact that the JRAD remedy no longer exists to palliate the deportation power in such cases, it

234. Immigration Act of 1917,39 Stat. $874,889-890$ (emphasis added).

235. 53 CONG. REC. at 5169.71 (1894).

236. 39 Stat. 889-890. 
having been abolished in 1990. Thus, two of the underpinnings of the imprisonment-before-deportation position-the claim that post-arrival criminals of moral turpitude should not be deportable, and the JRAD remedy for those who are deportable-no longer exist. This strengthens the case that a new policy of deportation before significant imprisonment in the United States has occurred.

In the aftermath of the passage of the Act of February 5, 1917, lawmakers proposed various amendments to the Act generally, and to its deportation provisions specifically. Here again, the wisdom of having post-arrival criminal aliens serve out their prison sentences in the United States before being deported was barely addressed. Just as before the passage of the act, this particular issue was lumped together with policy proposals that were far more contentious. Accordingly, Congress's attention was directed elsewhere. ${ }^{237}$

With one significant exception, the law governing the deportation of criminal immigrants remained essentially stable until enactment of the landmark McCarran-Walter Act of 1952, discussed immediately below. The exception was a statutory change in 1929, which essentially reworded the imprisonment-before-deportation provision to read that the criminal "shall not be deported under any provision of law until after the termination of the imprisonment. $" 238$ The reason that the statute was revisited in 1929, according to the legislative historian E.P. Hutchinson, was that Congress was concerned about deported criminals re-entering the country and thought "that punishment beyond deportation or redeportation was called for,... [and therefore] acted to make reentry by a previously deported alien a felony punishable by imprisonment of up to two years, a fine of up to $\$ 1,000$, or both

237. See e.g. 56 Cong. Rec. 8108, 8109-10 (1918). Responding to a bill that would tighten the Act of February 5,1917 with respect to the exclusion and deportation of anarchists, Representative Rogers asked why aliens who return to this country after being deported, and are therefore guilty of a felony, should need to stand trial and serve out their prison sentences before being deported yet again:

I wondered if there might not be cases where it would be desirable for the Secretary of Labor to have authority to deport at once without subjecting him to the absolute necessity of having this man tried for a felony? It seems to me the quicker you can get rid of cattle of this kind the better, and as the law now stands there must be first the trial and conviction and imprisonment, and only then at the conclusion of the imprisonment the deportation.

In his response, Representative Burnett, the author of the bill, suggested that this policy had not been interrogated so rigorously:

I do not know that there would be any serious objection to the suggestion of the gentleman.

This was the idea, however, that the man that came back after he had been deported had better be put into a prison, because if you deport him again maybe next week he will return, and so on ad infinitum; and if he should return, under this bill he could at once be tried and convicted of felony and imprisoned, and at the end of the term of imprisonment be deported . . I will give careful consideration to the suggestion.

The conversation then quickly turned to the more contentious matters, such as the legal definition of "anarchist."

238. Act of March 4, 1929, $\$ 3,45$ Stat. 1552. The provision continued: "For the purposes of this section the imprisonment shall be considered as terminated upon the release of the alien from confinement, whether or not he is subject to rearrest or further confinement in respect of the same offense." 
fine and imprisonment. ${ }^{, 239}$ In the same enactment, Congress inserted the new wording for the provision quoted above.

The provision was next revisited in the McCarran-Walter Act of 1952, a comprehensive overhaul of the immigration statute, which introduced most of the language of the provision as it is now codified in Section 241(a)(4):

An alien sentenced to imprisonment shall not be deported until such imprisonment has been terminated by the release of the alien from confinement. Parole, probation, or possibility of rearrest or further confinement in respect of the same offense shall not be ground for deferral of deportation., 240

Although semantic changes were made in 1952, this particular provision was eclipsed by the many other controversial issues that dominated the immigration policy debates of the day, as it had been in 1917 and thereafter.

\section{1993: The Unsuccessful Schumer Amendment}

The only serious effort to modify the imprisonment-before-deportation rule occurred in 1993, when Representative (now Senator) Charles Schumer introduced an amendment that would authorize the Attorney General to deport aliens sentenced to imprisonment before the termination of their sentences if the Attorney General "determine[d] that the alien has been adequately punished and that such deportation of the alien is appropriate," or approved the request of a state official who had made the same determination for state inmates. ${ }^{241}$ The bill did not pass. ${ }^{242}$ The record from a 1994 hearing on immigrant criminals reveals reasons why some other lawmakers opposed the Schumer amendment-and why some lawmakers today might likewise oppose the reform proposed in part $\mathrm{V}$ of this paper. ${ }^{243}$

First, although the Schumer amendment would only permit deportation of those criminals determined to have been "adequately punished," some

239. E.P. Hutchinson, Legislative History OF American Immigration Policy: 1798-1965, at 448 (1981).

240. Immigration and Nationality (McCarran-Walter) Act of 1952, Pub. L. No. 414, ch. 477, 66 Stat. $163,212$.

241. Criminal Aliens Incarceration Act of 1993, H.R. 2438, 103d Cong. 2 (1993). The bill would also have authorized judges sentencing "aggravated felon" immigrants to "declare" them deportable, which the provision seemed to make tantamount to an order of deportation, and in addition would require the Attorney General to take into federal custody "undocumented criminal aliens" upon request by an appropriate state official exercising authority over their incarceration. Id. at 3-4.

242. David Yassky, then counsel to Representative Schumer on the immigration subcommittee, does not recall why the amendment failed but assumes that it was because of concerns that the criminals would return to the U.S. Telephone interview, Aug. 3, 2010.

243. See Criminal Alien Deportation Legislation: Hearing on H.R. 723, 1067, 1459, 1496, 2306, 2438, H.Con.Res. 47, H.R. 2041, 2730, 1279, 2993, H.R. 3302, and H.R. 3320 (Title IV) Before the H. Comm. on the Judiciary, Sub. Comm. on Int'l Law, Immigration and Refugees, 103d Cong. (1994). 
lawmakers still expressed concern about whether adequate punishment could be assured if they did not complete their sentences. ${ }^{244}$

Second, some worried that deporting immigrant criminals before they completed their full sentences here would exacerbate the problem of their illegal reentry. As Representative Henry Hyde put it:

[O]ne of the problems with arresting an illegal alien for committing a crime and deporting him immediately is that many times they are deported and do no time at all for the crime they have committed and, because our borders are so porous, come right back in to commit another one, never having been punished for the original crime, and that creates a dilemma, because if someone has committed a crime, they ought to do some time and then be deported... [B]ut if they are deported immediately upon arrest because they are illegally in the country, it may be ... they go back to their own country where they are not going to go to jail in their own country. ${ }^{245}$

In response to Representative Hyde's concern, Representative Schumer first agreed ("Right, I agree with the gentleman, that is a real dilemma, and we certainly want people who commit crimes here to serve. The case I have documented is after they have served."), but then clarified that his legislation pertained only to immigrants who had already served some amount of their sentences. Representative Schumer then continued: "You know, all they have to do is find out from the local correctional authorities that Mr. X is supposed to get out in 6 months and have the documents prepared so after they have served their sentence they are deported, and they are not."246

Representative Bill McCollum noted that the states were divided on this issue according to the size of their incarcerated criminal alien populations:

There is a diversity of opinion as to whether criminal aliens should be deported prior to completion of their sentence... States such as California that are very concerned about the high incidence of reentry of deported criminal aliens and recidivism by these aliens, support completion of sentences prior to deportation. Other states, such as New York and Florida, tend to be more supportive of allowing, but not mandating deportation prior to completion of an alien's sentence. ${ }^{247}$

Representative Romano Mazzoli asked Representative Hunter (whose state, California, opposed early deportation), " $[\mathrm{H}]$ ave you analyzed ... the fact that in some cases [immigrant criminals] may be so swiftly deported that

244. Id. at 63 (remarks of Representative Canady).

245. Id. at 123 .

246. Id.

247. Id. at 156. 
they don't really suffer anything for the crime that they committed, and so they may be more prone to come back? I don't know whether that is a factor." ${ }^{248}$ Representative Hunter cited INS statistics to suggest that this was indeed a problem, "Yes, the briefing I got, Mr. Chairman, was from INS with respect to some 300 criminal aliens who had done time and were taken back, and then they checked to see how many were apprehended again on the border, and it was 10 percent within a few weeks, indicating a lot of them had come through." 249

A third argument against the Schumer bill was that, as INS officials proposed, Congress should focus on strengthening the deportation apparatus already in place, namely the Institutional Hearing Program (IHP), which was the predecessor of the current CAP, rather than diverting resources towards deporting immigrant criminals before completion of their sentences. ${ }^{250}$ As INS Deputy Commissioner Chris Sale put it, "The INS prefers to maintain the institutional hearing process as the centerpiece of our criminal alien removal strategy." 251 Representative Anthony Beilenson agreed, "These are problems that do not require a change in the law, they require only more will and perhaps more resources to enforce the law we already have."252

Fourth, some lawmakers, prefiguring a current theme in immigration debates, wanted to focus on securing borders, which they argued would prevent the entry of such criminals in the first place.$^{253}$ Congress, in enacting the AEDPA and IIRIRA of 1996, its major overhaul of the statutory provisions facilitating the deportation of immigrant criminals, codified the imprisonment-before-deportation provision, Section 241 (a)(4)(A) in its present form:

Except as provided in section 259(a) of Title 42 and paragraph (2), the Attorney General may not remove an alien who is sentenced to

\footnotetext{
248. Id. at 138 .

249. Id.

250. Id. at 178 (statement of Chris Sale, Deputy Commissioner, Department of Justice, Immigration and Naturalization Service: "[judicial deportation] could be efficient, it also could exacerbate Federal court docket delays and would require a commitment of INS resources at an earlier stage of the criminal process. The Administration prefers improving the Institutional Hearing Program (IHP), as announced by the Attorney General on February $3 \mathrm{rd}$. We are concerned that this provision could result in an increased burden on the Federal courts and prosecutors, a lack of uniformity in granting discretionary relief (currently the Board of Immigration Appeals (BIA) provides guidance through precedent decisions in this regard), and possible expansion of aliens' mandatory rights resulting from merging the deportation determination with the criminal process.").

251. Id. at 176 .

252. Id. at 172 .

253. As Representative Hunter put it, "[A]bsent a strong, enforceable border, we can solve other immigration problems by [other measures] but we will still have the criminal alien problem." Representative Mazzoli echoed this concern, "[W]hat we are talking about ultimately is a problem of not keeping people out in the first place who have no reason to come in, and so the other things we are dealing with, criminals in jails ... all of these vexing questions really could be prevented if we were able to keep them out, and so let me go back to what you were saying about the addition of 5,000 Border Patrol people." Id. at 129-30.
} 
imprisonment until the alien is released from imprisonment. Parole, supervised release, probation, or possibility of arrest or further imprisonment is not a reason to defer removal. ${ }^{254}$

\section{1996: The Statutory Exceptions to the Imprisonment-Before- Deportation Rule}

At the same time, Congress added a subsection (B) containing two largely parallel exceptions to Sec. $241(\mathrm{a})(4){ }^{255}$ These exceptions were similar to the Schumer proposal from the preceding Congress, although Schumer would have delegated discretion to corrections officials as to which criminals would be deported early, whereas subsection (B) limited early deportation to those criminals who had committed certain non-violent offenses. For reasons that are discussed below, the present article prefers Schumer's approach of broader official discretion.

These two exceptions authorize the deportation of certain classes of non-violent criminals before they complete their sentences. The first exception, applicable to those in federal custody, allows the Attorney General to deport the immigrant early if (1) the immigrant is confined for most nonviolent offenses, ${ }^{256}$ and (2) the Attorney General determines that the removal "is appropriate and in the best interest of the United States." 257 The second exception concerns criminals in state or local custody convicted of a nonviolent offense (again, with some specified exceptions). ${ }^{258}$ These exceptions authorize removal before the criminal serves his sentence if (1) the appropriate state official determines that early removal is appropriate and in the best interests of the state, and (2) requests the Attorney General to approve it. ${ }^{259}$

ICE has implemented a voluntary program under this second exception for nonviolent offenders in state custody. The program, called Rapid REPAT (Removal of Eligible Parolees Accepted for Transfer), is voluntary for both the participating state and immigrant inmates within the state. ${ }^{260}$ In

\footnotetext{
254. 8 U.S.C. $\$ 1231$ (a)(4)(A) (2006).

255. See 8 U.S.C. $\$ 1231$ (a)(4)(B) (2006).

256. This exception does not extend to "an offense related to smuggling or harboring of aliens" or
} to certain specified "aggravated felonies" (i.e., illicit trafficking in a controlled substance, firearms, destructive devices, or explosive materials; certain offenses relating to explosives, firearms, child pornography, and national security information or undercover agents). 8 U.S.C. $\$ 1231$ (a)(4)(B)(i).

257. Id.

258. 8 U.S.C. $\$ 1231(\mathrm{a})(4)(\mathrm{B})(\mathrm{ii})$. This exception does not extend to certain firearms and explosive or destructive materials offenses.

259. In IIRIRA, Congress added the exception referring to "section 259(a) of Title 42" which remains in the U.S. Code, even though the Section 259 of Title 42, was repealed in 2000. 42 U.S.C. 259(a) had required the deportation of non-citizen drug addict convicts directly from hospitals, if they had been incarcerated there, rather than having them return to a penal institution to serve out the remainder of their sentences. This statute was repealed in 2000. Pub.L. 106-310, Div. B, Title XXXIV, $\$ 3405$ (a), 114 Stat. 1221 (repealed 2000).

260. U.S. Immigration \& Customs Eniorcemint, Fact Shisit: ICE RapiD Replist Progiram I (2009), available at http://www.ice.gov/doclib/news/library/factsheets/pdf/rapidrepat.pdf. 
participating states (California is not among them), ${ }^{261}$ inmates who have been convicted of nonviolent offenses and meet other eligibility requirements may receive early conditional release if they have a final order of removal and they agree to return to their country of origin and not to come back to the United States. ${ }^{262}$ The Rapid REPAT Program is discussed further in Appendix 3.

The limited legislative history of these (B) exceptions indicates that they were adopted with no evident dissent, and under the same policy logic advanced by this article: that federal and state prisons contain a large number of criminal immigrants; that a substantial number of these criminal immigrants are legally removable simply by reason of their criminal convictions; that removing them would reduce prison overcrowding, incarceration costs, and recidivism in the U.S. associated with these criminals; and that enhanced penalties for illegal re-entries by those removed would deter such re-entries. ${ }^{263}$

Although use of this early-removal authority has been growing gradually, it is striking that these removals involve criminals who have already served a good part of their sentences rather than removing criminals before or soon after they are imprisoned. A history of how the federal government and the states have implemented (or failed to implement) this authority is presented in Appendix 3.

\section{Congress's Growing Demand for the Deportation of IMMIGRANT CRIMINALS}

During the 1980s and 1990s, congressional concern about immigrant crime reached its zenith. ${ }^{264}$ In 1986, 1988, 1990, 1991, 1994, and twice in 1996, Congress debated and passed laws targeting immigrant criminals and immigration law enforcement agencies (then combined in the Department of Justice (DOJ), especially the Immigration and Naturalization Service (INS)) ${ }^{265}$ Key committees held hearings on the subject of immigrant crime nearly every year from 1986 to $1998 .^{266}$ As early as 1985 , members commissioned detailed reports from the Government Accountability Office $(\mathrm{GAO}) .{ }^{267}$ Immigration officials regularly testified on the subject before

261. See infra app. 3, at 4-5.

262. Id.; Rapid REPAT, U.S. IMMIGRATION \& CUSTOMS ENFORCEMENT, http://www.ice.gov/rapid repat/ (last visited Feb. 12, 2012).

263. For a more detailed account of the legislative history, see Katherine Reisner, Legislative History of (B) Exceptions, (attached to email dated Dec. 30, 2010) (on file with author).

264. The discussion in this Part covering the period up to 1998 draws heavily, sometimes verbatim, from Schuck \& Williams, supra note 30, part IV. Most of that article focused on how law-enforcement federalism affected policies designed to more quickly and effectively deport immigrant criminals.

265. Id . at 423 .

266. Id.

267. Id. 
congressional committees. ${ }^{268}$ Despite budgetary austerity, Congress more than doubled the size of the INS budget in the six years between 1993 and 1999 , with much of the increase flowing to the deportation system. ${ }^{269}$

As Congress learned during this period, the system for deporting immigrant criminals was remarkably ineffective. According to a study published in 1986, during one period of fifteen months, as many as ten percent of arrested felons in New York City were immigrants. ${ }^{270}$ Without sufficient investigative staff to interview immigrant arrestees, the INS district offices screened only about one in nine of them before local law enforcement agencies, which had made the arrests, released them. ${ }^{271}$ Those who did wind up in deportation proceedings languished there for months, and, with only 400 detention beds available to the district office, many were released. ${ }^{272}$ Although those who remained in detention were generally removed within ninety days of apprehension, only 17.5 percent of those released over the three years prior to the study were actually deported. ${ }^{273}$ Of those released, 24 percent absconded, and 35 percent were arrested for new crimes. ${ }^{274}$ In one sample of arrestees investigated by the INS, 21 percent had been deported previously. ${ }^{275}$ The GAO found that many of the immigrant criminals removed from the New York City area were never even listed in the data systems used to screen entry into the United States. ${ }^{276}$

This information about the fecklessness of the government's efforts to deport immigrant criminals, even after Congress had begun to pay serious attention to the problem, was very disturbing not only to Congress and the general public, but also and especially to politicians from states that have large immigrant populations, such as like Florida and New York. ${ }^{277}$ After all, the causes and nature of the problem were evident, and possible solutions had begun to emerge, as early as $1986 .{ }^{278}$

In 1986, the INS launched its Alien Criminal Apprehension Program (ACAP) ${ }^{279}$ which aimed to work with local agencies to begin deportation proceedings even before conviction. ${ }^{280}$ The IHP, created in 1988, sought to commence deportation proceedings for inmates in federal and state prisons

268. Id.

269. Id. at 424 .

270. Id. at 425 .

271. Id.

272. Id. at $425-26$.

273. Id. at 426 .

274. Id.

275. Id.

276. Id.

277. Id. at 432-33.

278. Id. at 432 .

279. Criminal Aliens: INS Enforcement: Hearing Before the H. Subcomm. On Immigration, Refugees and International Law, 101 st Cong. 7-8 (1989) (statement of Lowell Dodge, Director, Administration of Justice Issues, General Government Division), available at http://archive.gao.gov/ d48t13/139869.pdf.

280. Schuck \& Williams, supra note 27 , at $427-28$. 
before the completion of their sentences by bringing together attorneys, immigration judges, and incarcerated aliens in order to expedite the process, thus eliminating the need for further detention by the INS. ${ }^{281}$

In 1988 [STET], Congress created a new class of immigrant criminals"aggravated felons"-and sharply limited their legal rights. ${ }^{282}$ It curtailed their access to discretionary relief, forced them to file expedited appeals, and subjected them to more stringent re-entry conditions and penalties. ${ }^{283}$ The 1988 law contained some managerial directives, such as mandating the IHP by statute, and requiring the agency to take all aggravated felons into custody without bail upon completion of their sentences if their removal hearings had not yet been completed. Nevertheless, the deportation process remained notoriously ineffective. ${ }^{284}$

In 1990, a frustrated Congress rewrote deportation law. It imposed higher penalties for non-appearance at deportation hearings, eliminated JRAD relief, ${ }^{285}$ expanded the definition of aggravated felony, and further penalized anyone who committed an aggravated felony. ${ }^{286}$ In the years following, however, there was little additional funding of deportation enforcement and the problem of criminal immigrants continued to grow. ${ }^{287}$ The government continued to lose ground against them. ${ }^{288}$

By the beginning of 1994, however, Congress's detachment and the INS's passivity were coming to an end. The INS began to request substantial new resources to build a new deportation infrastructure. Congress began to support the INS, meeting or exceeding the administration's sizeable requests each year. The most important cause of this shift was the political muscle exerted by California and Florida politicians. During this period, Congress again expanded the definition of aggravated felony, created a streamlined administrative deportation procedure, eliminated the right of certain immigrant criminals to seek discretionary relief from deportation, and permitted judges in federal criminal cases to order deportation. It also substantially

281. 2002 OIG AUDIT REPORT, supra 62 at 1.

282. Id. at 433-34.

283. Id. at 434 .

284. Schuck \& Williams, supra note 30 , at $433-37$.

285. "In sharp contrast to the legislative debate that marked the enactment of JRADs in 1917, Congress eliminated this provision without much discussion at all. In the crime control bill that became part of the Immigration Act of 1990, the House of Representatives originally proposed to limit JRADs by excluding convictions for the recently enacted aggravated felony deportation ground. The bill was amended, however, to repeal JRADs altogether. Proponents of JRADs (including some state court judges) lobbied for Congress to retain this provision, but the issue was never addressed in congressional debates. Instead, JRADs were simply washed out of the statute among the waves of increasingly harsh congressional measures intended to crack down on noncitizen criminal offenders." Margaret H. Taylor \& Ronald F. Wright, The Sentencing Judge as Immigration Judge, 51 EMORY L.J. $1131,1150-51$ (2002).

286. Schuck \& Williams, supra note 30 at 438 \& n.362. Further penalization included barring the felon from seeking asylum and limiting the time for appealing deportation orders, among other measures.

287. Id. at $438-43$.

288. Id. 
increased funding for deportation enforcement, further restricted criminals' procedural defenses, and authorized several new routes to deportation. ${ }^{289}$

In 1996, Congress passed the most stringent provisions governing deportation of immigrant criminals yet adopted. ${ }^{290}$ It once again expanded the definition of aggravated felony, lowered the sentencing threshold required to make certain crimes the basis for deportation, and subjected most immigrant criminals to summary deportation. ${ }^{291}$ Additionally, Congress foreclosed almost all forms of relief for such criminals unless they were long-term legal residents and permitted state and local law enforcement officers to arrest and detain immigrants who had been previously convicted of a felony and deported ${ }^{292}$ Significantly, it also required the INS to take custody of most incarcerated immigrant criminals upon completion of their sentences, but postponed implementation of this requirement due to insufficient detention space. $^{293}$

In 1998, the IHP transitioned into the Institutional Removal Program (IRP). ${ }^{294}$ At that point, ACAP and the IRP had similar functions-with ACAP tasked with picking up coverage of U.S. penal institutions not covered by the IRP. ${ }^{295}$ By the end of the decade, the INS had substantially increased the number of IRP hearings and the screenings of prisoners in local jails with large immigrant populations. ${ }^{296}$ The INS improved its information systems and coordination both internally and with local law enforcement. Congress had dramatically increased the INS's own enforcement resources. Most interesting in light of the "imprisonment-before-deportation" policy, Florida and New York had established programs that qualified for the aforementioned statutory " $B$ " exception to this policy that Congress had authorized in 1996, which allows states to deport immigrant criminals before the end of their prison terms if they were convicted of certain non-violent offenses. ${ }^{297}$

Despite this progress, audits and reports continued to find the IRP inadequate. ${ }^{298}$ In a 2002 report, the Office of the Inspector General (OIG)

289. Id. at $443-50$.

290. Id. at 450 .

291. Id.

292. Id.

293. Id.

294. E.g., US Dep't of Justice, Office of the Inspector General, Audit Report: Immigraiton \& Naturalization Service Institutional Removal Program, 02-41 (Sept. 2002), available at http://www. justice.gov/oig/reports/INS/a024l/final.pdf.

295. Id. at 4.

296. Id.

297. Id. at $450-54$

298. See H.R. RliP. No. 107-807, at 319 (2003) ("INS's record in removing criminal aliens from the United States has also been uneven, at best. GAO has identified criminal alien removal as 'one of INS's long-standing challenges.' The INS's experience with its Institutional Hearing Program is indicative of its inconsistent performance in identifying and removing criminal aliens."); see also H.R. Ris. No. 105-636, at 35 (1998) (rejecting the Administration's proposal to expand the IRP, in light of the INS's failure to meet program goals despite having received increased resources for the IRP; noting "less than 30 percent of eligible prisoners complete IRP processing before they leave prison, and an even smaller percentage actually are deported.”); H.R. RI:P. No. 106-479, at 152 (1999) 
found that the IRP had been utterly unable to keep up with the number of incarcerated criminal immigrants eligible for removal, which had increased dramatically due to the 1996 immigration laws. The IRP's biggest failings were at the county level, as the program lacked substantial coverage for even the most basic of the IRP functions: identification of criminal immigrants eligible for removal. As such, the report stressed the identification of all criminal immigrants in the United States as a top priority for the INS and IRP. ${ }^{299}$ A markedly improved IRP, the report continued, would require the "full cooperation of state and local governments," which the federal government could achieve by using whatever leverage it possessed. ${ }^{300}$ Five years later, another OIG audit found that the level of cooperation between federal immigration officials and law enforcement officials under the IRP varied widely among jurisdictions. ${ }^{301}$ Some cities actively discouraged or limited local participation in immigration law enforcement. For example, San Francisco allowed ICE agents to enter local jails, but not to access files, thereby impeding IRP's successful operation. ${ }^{302}$ Subsequent changes to the IRP have sought to remedy such criticisms. Although immigration advocates have also criticized the remote locations of some facilities, which can impede access to counsel, one court has rejected a challenge to such siting. ${ }^{303}$

Beginning in 2005, ACAP and the IRP were largely absorbed into the current Criminal Alien Program (CAP). By June 2007, CAP had come under the full control and supervision of ICE's Office of Detention and Removals (DRO). ${ }^{304}$ The IRP was to conduct all necessary removal proceedings before release from prison so that the incarcerated criminal could be promptly deported upon release without spending much or any time in ICE detention. CAP, by contrast, only took responsibility for identifying incarcerated criminal immigrants and delivering them to ICE custody at the end of their sentences so that they did not abscond upon release. ${ }^{305}$ While CAP coverage

(Conf. Rep.) (directing the INS to demonstrate to the Committees on Appropriations that the IRP gives "priority to aliens imprisoned for serious violent felonies or drug trafficking," or "to explain why and to outline the steps [the INS] will take to focus IRP efforts on the most dangerous incarcerated aliens.") cited in Christopher N. Lasch, Enforcing the Limits of the Executive's Authority to Issue Immigration Detainers, 35 W. MITCHELL L. REv. 164, n.19 (2008).

299. 2002 OIG AUDIT REPORT, supra note 62 at 7.

300. Id. at 20 .

301. U.S. Dep't Of Justice, Office Of The Inspector Gen., Audit Div., Cooperation Of SCAAP Recipients In The Removal Of Criminal Aliens From The United States 9-10 (2007).

302. Id. at 10, 18-19 (describing ICE relationship with San Francisco Sheriff's Department as "unfriendly and marked by 'much animosity" ).

303. Roshan v. Smith, 615 F. Supp. 901 (D.D.C. 1985).

304. Strengthening Interior Enforcement: Deportation and Related Issues: Hearing on Before the S. Comm. on the Judiciary, Subcomm. on Immigration. Border Sec., \& Citizenship, and Subcomm. on Terrorism, Tech. \& Homeland Sec., 109th Cong. 9 (2005) (statement of Victor X. Cerda, Acting Director of ICE Office of Detention and Removal (DRO)); U.S. IMMIGRATION AND CUSTOMS ENFORCEMIENT, ICE FISCAL YEAR 2008 ANNUAL REPORT, 3.

305. Financial Impact of lllegal Immigration on Border Communities: Hearing on H.R. 4437 and S. 2611 Before the H. Comm. on the Judiciary, 109th Cong. 6 (2006) (statement of Alison Siskin, Specialist in Immigration Legislation, Cong. Research Service). 
at the federal level was robust, many state and local systems failed to routinely notify ICE when they had criminal immigrants in custody. Consequently, many of them were released after completion of their sentences rather than being taken into ICE custody. This failure made it more difficult to locate the aliens for deportation and increased the risk that they would commit new crimes. ${ }^{306}$

More recently, the federal government has tried to increase the state and local coverage of both CAP and the IRP by expanding the menu of options for law enforcement assistance of state and local agencies. ${ }^{307}$ CAP is now one of fourteen such cooperative programs, and one of three "jail status check" programs (along with the Section $287(\mathrm{~g})$ and Secure Communities programs, described below). ${ }^{308}$

CAP/IRP has had a significant effect. Of the 71,063 criminal aliens removed by the INS in 2001, 30,002 were removed through the IRP. ${ }^{309}$ In 2012, the Department of Homeland Security (DHS) deported a record number of 409,849 immigrants of whom nearly 55 percent 225,390 had criminal records. ${ }^{310}$ DHS reports that this is almost double the removal of criminals from FY 2008. ${ }^{311}$ CAP is now screening inmates in all 114 federal prison facilities, ${ }^{312}$ substantially benefiting from video teleconferencing technology that enables screening interviews in federal prisons to be conducted remotely. ${ }^{313}$

While immigrant advocacy groups severely criticize the Obama administration for its record number of removals of criminals, ${ }^{314}$ many members of Congress remain unsatisfied with these results, noting that the number of immigrant offenders removed still represents fewer than half of the 450,000 criminals whom ICE estimates are eligible for deportation and who are in penal custody in any given year. ${ }^{315}$ Moreover, many deportable immigrant criminals still end up slipping through the agency's enforcement net and disappear at the end of their prison terms before ICE can effectuate their

\footnotetext{
306. Id.

307. ICE, Criminal Alien Program (January 25, 2014), http:/www.ice.gov/criminal-alien-program/.

308. Id.

309. 2002 OIG AUDIT REPORT, supra 62 at i.
}

310. News Releases, FY 2012: ICE announces year-end removal numbers, highlights focus on key priorities and issues new national detainer guidance to further focus recourses, ICE, Dec. 21, 2012, http://www.ice.gov/news/releases/1212/121221 washingtondc2.htm.

311. Id.

312. U.S. IMMIGRATION AND CUSTOMS ENFORCEMENT, supra note 304 at 3.

313. In 2006, ICE launched Detention Enforcement and Processing Offenders by Remote Technology (DEPORT), which uses this technology to identify criminal aliens in federal custody by conducting interviews of inmates in locations nationwide from a central location in Chicago. Dep't of Homeland Security, Fact Sheet: Ice Accomplishments in Fiscal Year 2006, Oct. 30, 2006. hitp:// immigration.procon.org/sourcefiles/ice2006achievements.pdf.

314. See, e.g., Corey Dade, Obama Administration Deported Record 1.5 Million People, NPR (Dec. 24, 2012, 5:00 PM) http:/www.npr.org/blogs/itsallpolitics/2012/12/24/167970002/obamaadministration-deported-record-1-5-million-people.

315. COMM. ON APPROPRIATIONS, supra note 40. Assessments of effectiveness seem to be based on the number of removals, the number of charging documents issued by ICE, or both. 
deportation. ${ }^{316}$ The Republican members of the Senate Judiciary Committee wrote to DHS Secretary Janet Napolitano on October 20, 2010, accusing ICE of "a lax approach," citing an ICE directive advising its attorneys to seek dismissal of all cases involving criminal aliens who have committed fewer than two felonies and are not guilty of an aggravated felony. ${ }^{317}$ President Obama's June 2012 executive order establishing the Deferred Action for Childhood Arrivals program, which suspended deportations for millions of young undocumented immigrants, greatly intensified this criticism. ${ }^{318}$

Two other jail-related programs-Section $287(\mathrm{~g})$ and Secure Communities-also affect the deportation of criminal immigrants. Under section 287(g), DHS entered into agreements with designated state and local law enforcement officers to perform a range of immigration enforcement duties under ICE supervision. ${ }^{319}$ After much criticism of this program, it was largely supplanted by another program: Secure Communities, established by the Bush administration in 2008, which DHS viewed as a better channel for local participation. ${ }^{320}$

Secure Communities gives ICE a technological rather than a physical presence in prisons and jails; thus, the program does not require much, if any, additional state and local agency resources or on-site presence by ICE officers. ${ }^{321}$ Participating jails in participating jurisdictions submit arrestees' fingerprints to FBI criminal databases, and that information is automatically transmitted to a DHS database containing biometric information on all legal, and some illegal, entrants. ${ }^{322}$ Fingerprints typically get transmitted as part

316. See, e.g., Julia Preston, National Briefing I Immigration; 596 Arrested in Sweep, N.Y. TIMI:s, May 1, 2010, at A12 (reporting that the head of ICE says many of the immigrants apprehended in a recent raid had eluded deportation when released from prison after serving criminal sentences). ICE may also release convicted criminals because removal cannot be effectuated for a variety of reasons. ICE estimates that it released 6,191 convicted criminals in 2010 because removals were not possible. Immigration and Customs Enforcement, Criminal Alien Statistics, March 15, 2011 (on file with author). Of these criminal immigrants, 641 bonded out, 15 were deported, 6 escaped, 2 were released on humanitarian or medical orders of recognizance, 514 were otherwise released on an order of recognizance, 4,983 were released on orders of supervision, 28 were paroled, and 2 were withdrawn. Id.

317. Press Releases, 'Catch and Release' Good for Trout, Bad Policy for Criminal Aliens (Oct. 21, 2010), http://www.hatch.senate.gov/public/index.cfm/releases?ID=d0932d2e-1b78-be3ee00e-f44fd $4 \mathrm{e} 36873$. The senators also wanted to know the cost of deporting "every illegal alien" arrested by ICE agents.

318. E.g., Robert J. Delahunty \& John Yoo, Dream on: The Obama Administration's Nonenforcement of Immigration Laws, the Dream Act, and the Take Care Clause, 91 Tix. L. RI:v. 781, 783-84 (2013)

319. Dep't of Hombland Sec., OfFice of Insplictor Gen., OIG-10-63, The Pierlormancle ol: 287(g) AGREEMENTS 2-3 (2010).

320. E-mail from Adam Cox, Professor of Law, New York University School of Law, to author (July 30, 2013) (on file with author).

321. Secured Communities: Get the Facts, ICE (Jan. 25, 2014), http://www.ice.gov/secure communities/get-the-facts.htm. See generally, Peter H. Schuck, Op-Ed.,Three States Short of a Secure Community, N.Y. TIMEs, June 23, 2011 , at A27 (describing program, criticizing governors who decline to participate, and urging reforms).

322. U.S. IMMIGRATION AND CUSTOMS ENFORCEMENT, SECURE COMMUNITIES: QUARTI:RIY RI:PORT, FisCal. Year 2010 Report to Cong., THIRd Quarter 2-3 (2010). 
of the booking process, which can occur at a jail but can also occur at other locations, such as a police precinct. ${ }^{323}$ This information can then be compared to information on individuals held in jails. Because Secure Communities does not require agreements with or deputizing of local law-enforcement agencies, it can be deployed much more rapidly than section $287(\mathrm{~g})$ or CAP/ IRP programs. Secure Communities has become a central part of President Obama's enforcement strategy-nationwide implementation was initially planned for 2013-which prioritizes removing immigrants convicted of serious crimes over workplace raids. ${ }^{324}$ Secure Communities has aroused much opposition by immigrant advocate groups and some states and localities that believe that it instills more fear in immigrant communities and reduces their cooperation with the police. ${ }^{325}$ Nevertheless, as of January 22 , $2013,3,181$ jurisdictions, including $100 \%$ of the counties in the United States, had activated Secure Communities. ${ }^{326}$

These programs, however, are all constrained by the overriding "imprisonment-before deportation" rule. The next Part examines the nature of those constraints.

\section{Arguments Against Changing the "Imprisonment-Before- DEPORTATION" Rule}

Legislative inertia can explain a great deal of public policy stasis, but does not explain the whole story. In the case of the imprisonment-beforedeportation rule, more plausible arguments explain the resistance to changing the rule. This Part discusses six of these possible arguments: (1) fear of illegal re-entries; (2) concern about reduced deterrence; (3) the PTT regime; (4) the moral claims of immigrant criminals who are long-term residents of the United States; (5) the competition for limited enforcement resources; and (6) political factors. Notably, the United Kingdom encourages early removal of immigrant criminals in the face of presumably similar conditions and arguments. $^{327}$

323. Supra note 264.

324. Doris Meissner, Donald M. Kerwin, Muzaffar Chishti, \& Claire Bergeron, IMMICiRATION Enl:orciamint in thi: Unitiad Statis: thi: Risl: ol: a Formidabli: Machinery 5-6, Migration Policy Institute (January 2013), http://www.migrationpolicy.org/pubs/enforcementpillars.pdf.

325. See, e.g., Miriam Jordan, States Rebel Over Deportations, WAI.L. ST. J. (May 14, 2011) at A3; Kirk Semple \& Julia Preston, Deal to Share Fingerprints Is Dropped, Not Program, N.Y. TIMES (Aug. 6, 2011) at A11; Julia Preston, Deportation Program Sows Mistrust, U.S. Is Told, N.Y. TIMES (Sept. 16, 2011) at A 12; Abby Goodnough, Fatal Accident Puts Focus On Deportation Program, N.Y. Times (Sept. 30, 2011) at A13.

326. Adam J. Cox \& Thomas J. Miles, Policing Immigration, 80 U. CHI. L. REv. 87, 100; ICE, ACtivatei) Jurisidictions, (Jan. 25, 2014), http://www.ice.gov/doclib/secure-communities/pdf/ sc-activated.pdf.

327. Criminal Justice and Immigration Act 2008, c. 4, \$ 34(5) (U.K.); Criminal Justice Act 2003, c. 44, $\$ 260$ (1), (4) (U.K.); id. $\$ 262$, Sch. 20 (amending the Criminal Justice Act of 1991); The Early Removal of Fixed-Term Prisoners (Amendment of Eligibility Period) Order, 2008, S.I. 2008/978, (U.K.). Canada, however, adheres to an imprisonment-before-deportation policy. Immigration and Refugee Prot. Act, S.C. 2001, c. 27, Div. 5, \$ 50(b) (Can.). A regulation does authorize early removal 


\section{A. Fear of Illegal Re-entries}

The legislative history of the imprisonment-before-deportation rule, recounted in Part II, reveals a persistent concern by some members of Congress, particularly from the states bordering Mexico, that deporting immigrant criminals immediately, rather than waiting until after they have served their prison terms, has negative repercussions. These members argue that earlier deportations would simply accelerate criminal immigrants' illegal re-entry and further criminal activity. ${ }^{328}$ This concern is justified; a significant number of illegal re-entries do occur, and many of these re-entrants commit crimes in the United States. In 2010, orders of removal were reinstated for 102,809 immigrants who had been convicted of crimes after re-entering the United States following an earlier removal. ${ }^{329}$ Only 18,986 of these new convictions were for immigration offenses; the vast majority of new convictions were for a broad variety of crimes, including drug offenses, violent crimes, and property crimes ${ }^{330}$ However, available data suggest that the re-entry and recidivism rates for inmates transferred under the PTTs (discussed in Part IV.C. below) are fairly low. The inmates selected for transfer are chosen in part based on their likelihood of re-entry. From 2005 through 2010 , only 33 of the 1,100 inmates (3\%) tracked by available FBI data who transferred under the treaties returned to the U.S. and were re-arrested within a three-year period. ${ }^{331}$

The notion that imprisonment in the United States will reduce the probability of illegal re-entry, however, seems implausible. It is hard to see how imprisonment would reduce any incentive that a criminal might already have to re-enter the country. If instead the notion is that imprisonment in the United States would postpone his effort to re-enter until the prison term ends, its truth depends on whether the proposed alternative scenario- that he serve the same sentence in the country of origin rather than in the United States-is adopted. If it is, then the probability of re-entry is no greater than it is under the status quo of imprisonment in the United States. Thus, it is not clear why the United States would benefit from a mere delay, mandated by the current rule, of an attempted re-entry that, by hypothesis, will occur anyway. The same point applies to the fact that many criminals "age out"332 of crime as they grow older. Although longer incarceration will, to that extent, reduce

\footnotetext{
pursuant to agreement by the relevant Canadian officials. Immigration and Refugee Protection Regulations, SOR/2002-227, Div. 3 \& 234 (Can.).

328. See Restriction of Immigration, supra note 226, at 12-13 (discussion of congressional concerns about illegal re-entry).

329. See infra Appendix 4.

330. Id.

331. U.S. Dep't of Justice, OfFice of InSPECtor Gen., I-2012-002, The Department of Justice's International Prisoner Transfer Program 69 (2011) [hereinafter U.S. DOJ INT'L PTP].

332. See e.g. Terrie Moffitt, Adolescence-Limited and Life-Course: a Developmental Taxonomy, 100 Psychol. REv. 674, *3 (1993) (finding that adolescent boys involved in criminal activity is a "normal part of teenage life" and only about $5 \%$ are "life course persistent offenders.").
} 
recidivism by such criminals, the United States benefits if the criminals' aging out occurs in their countries of origin.

If, however, the criminal is deported to a country that does not make him serve his full sentence-a possibility that my proposal and the PTTs would preclude in most, but perhaps not all, cases ${ }^{333}$ - then the risk of earlier re-entry may indeed increase. Given that most in-prison rehabilitation programs are ineffective, ${ }^{334}$ the recidivism risk posed by those who do re-enter illegally is likely significant. In addition, the burdens of such recidivism, and thus the incentives concerning early deportation, may be different for federal, state, and local systems. ${ }^{335}$ Nevertheless, controlling that risk depends primarily on the effectiveness of border enforcement, which both the Bush and Obama administrations have attempted to strengthen with some apparent success. ${ }^{336}$ Furthermore, as discussed below, instituting a more effective PTT regime may reduce the risk of earlier re-entry.

\section{B. Concern About Reduced Deterrence}

A different, but related, concern is that a new deportation-beforeimprisonment policy would reduce both the specific and general deterrence created by our criminal laws. This loss of deterrence occurs either when the

333. See supra note 18.

334. See Barkow, supra note 65 , at 11-13. For information on rehabilitation programs in federal prisons, see Statement of Harley G. Lappin Director of the Federal Bureau of Prisons, U.S. SENTENCING COMm'N (Mar. 17, 2011), http://www.ussc.gov/Legislative_and_Public_Affairs/Public_ Hearings_and_Meetings/20110317/Testimony_BOP_Lappin.pdf.

335. Professor Barkow makes the interesting point that

[T] he incentives are a bit different for federal and local actors. For states, they pay the total cost of prisons..., whereas the risk that the offender might reenter the US is a federal concern and the risk the immigrant on re-entry goes on to commit another crime is one that could fall on another state. In other words, there's an externality problem for the states that might lead them to focus too much on the cost of incarceration and undervalue the risk of re-entry/value of deterrence by having an offender serve his full term. The federal government, in contrast, might undervalue the cost of incarceration ... and overvalue the risk of re-entry.

Email from Rachel E. Barkow to the author (March 21, 2011) (on file with the author).

336. Apprehensions by the U.S. Department of Homeland Security, Customs and Border Protection (CBP) Office of Border Patrol (OBP) steadily declined from 876,787 in 2007 to 463,382 in 2010. OfFice of Immigration Statistics, 2010 Yearbook of Immigration Statistics 93 (2011). Statistics on apprehensions are considered one of the few available indicators of illegal entry attempts. Nancy Rytina \& John Simanski, ApPrehensions by the U.S. Border Patrol: 2005-2008, FACt Sheet 1 (June 2009). Using a different methodology, the Pew Hispanic Center also estimates that the inflow of illegal immigrants has declined since 2007. The Pew Hispanic Center estimates that the inflow of unauthorized immigrants declined from an 850,000 average annually between March 2000 and March 2005, to a 550,000 average annually between March 2005 to March 2007, to a 300,000 average annually between March 2007 and March 2009. JEFFREY PASSEL \& D'VERA COHN, U.S. Unauthorized Immigiration Flows are Down Sharply Since Mid-Decade i (2010). The Pew method extrapolates from the March Supplements to the Current Population Survey, a survey of about 80,000 households conducted by the U.S. Bureau of Labor Statistics and the Census Bureau. The Center estimates the unauthorized immigrant population based on the Survey, and then based on data about the immigrants' arrival dates in the country, estimates the inflows of unauthorized immigrants. Id. at 27-28. However, the Center's methodology may exclude the many undocumented migrants who are immediately apprehended at the border and returned home. 
country of origin will not repatriate its errant national at all, or when it will repatriate him but then either not imprison him or imprison him for a term shorter than he would serve in the United States. It is true that some countries of origin resist repatriating their nationals whom they consider undesirable; serious criminals would surely fall into this category ${ }^{337}$ Such refusal, however, is a clear violation of international law, and the United States has often approached this problem diplomatically, sometimes with success. ${ }^{338}$ A refusal by the country of origin to repatriate the criminal will stymie deportation nonetheless, whether repatriation is sought before or after imprisonment. ${ }^{339}$

A more forceful defense of the status quo, however, imagines the following scenario: the country of origin agrees to repatriate its national before he serves his full sentence in the United States, but then imprisons him for a period shorter than he would serve here-or perhaps does not imprison him at all. If criminals can rely on such lenient treatment, the deterrent effect of American law, as well as any retributive motives that lie behind that law, may be weakened. Conversely, the prospect of being held in the more dangerous prisons of Mexico or other poor countries might cut the other way, possibly even increasing deterrence. One cannot confidently predict which of these possibilities would occur and to what extent, much less know how they will affect deterrence on balance. In addition, the United States could use various forms of diplomatic action to increase pressure on the other country to fully implement the U.S. sentence.

\section{Prisoner Transfer Treaties}

A major impediment to policy change is the current PTT regime. Transfers pursuant to these agreements typically require: (1) the prisoner's consent; (2) the receiving country's consent; (3) finality of the judgment against the foreign national; and (4) dual criminality (the crime for which the individual was convicted must be a crime in both the sending and receiving countries). In many but not all countries that are parties to such treaties, the prisoner must also initiate the transfer. ${ }^{340}$ In the United States, foreign national prisoners initiate applications for transfer, which are then evaluated

337. Keep Our Communities Safe Act of 2011: Hearing on H.R. 1932 Before the Subcomm. on Immigration Policy and Enforcement of the Comm. on the Judiciary, 112th Cong. $36-38$ (2011) (statement of Gary Mead, Executive Associate Director, Enforcement \& Removal Operations, U.S. Immigration \& Customs Enforcement); U.S. DOJ INT'L. PTP, supra note 329, at 53 (2011) (describing Mexico and Canada's refusal to repatriate certain inmates under the prisoner transfer treaties).

338. See U.S. DOJ INT'L. PTP, supra note 331, at 38-40, 102.

339. See Jama v. Immigration and Customs Enforcement, 543 U.S. 335 (2005) (holding that a deportable immigrant may be removed whether or not the country to which removal is sought refuses to accept the immigrant).

340. International Prisoner Transfer Program. How the Program Works, U.S. DEP'T OF JUsTICE, OFFICE OF ENFORCEMENT OPERATIONS, http://www.justice.gov/criminal/oeo/links/intlprisoner/intl prisoner.html (last visited Mar. 21, 2014). 
by the Department of Justice for approval. The DOJ considers the prisoner's likelihood of social rehabilitation and his likelihood of return to the United States, as well as law enforcement concerns as it determines whether to approve the transfer. ${ }^{341}$

Such treaties did not exist until a few decades ago. Traditionally, the United States ${ }^{342}$ and other nations $s^{343}$ took the position that for one country to implement the penal laws of another country would violate the sovereignty of the receiving state. Because the essence of PTTs is the execution in one country of the penal sentences dealt out by another, such treaties violated this norm.

That Congress eventually signed PTTs suggests that it had a powerful incentive to do so. This motivation only arose in the late 1970s when increasing numbers of U.S. nationals were being incarcerated in Mexican prisons, and vice-versa, largely due to bilateral efforts between the two countries, spanning the previous two decades, to combat narcotics trafficking. ${ }^{344}$ Whereas there were approximately 100 U.S. nationals in Mexican prisons in 1969, there were over 600 by October $1977 .^{345}$ Thus, the United States signed its first PTT in 1977 with Mexico. ${ }^{346}$ Mindful of American prisoners in foreign jails, Congress then expressed its intent that no transfer should take place without the prisoner's consent. "The requirement of the consent of the offender is not intended to be an expression of the view that transfer of offenders could not be accomplished without their consent, but rather an expression of a policy against involuntary transfer of civilian offenders in the international area." ${ }^{347}$

Congress seems to have required the prisoner's consent for two reasons, neither of which is convincing. The first concerned the treaties' humanitarian and rehabilitative purposes. As the Judiciary Committee noted at the time, "[i]ncarceration in one's own country is severe enough punishment. Service of a custodial term in a foreign jail creates special hardships upon the individual offender, and his family." ${ }^{348}$ Calling a jail "foreign," however,

341. International Prisoner Transfer Program, Guidelines for Evaluating Prisoner Transfer Applications, U.S. Di:p'T OF JUSTICl: OIlicl: OF ENIOURCI:MI:NT OPl:RATIONS, http://www.justice.gov/ criminal/oeo/links/intlprisoner/guidelines.html (last visited Mar. 21, 2014).

342. Chief Justice Marshall, writing for a unanimous Supreme Court, stated the norm that for centuries prior to the first prisoner transfer treaties, had prevailed internationally and in the United States: "The Courts of no country execute the penal laws of another . . ." The Antelope, 23 U.S. (10 Wheat.) 66, 123 (1825).

343. Michali. Plachta, Transhilir ol: Prisonirs Under intignational. Instruments and DOMI:STIC LEGISI.ATION 3 (1993).

344. Id. at 451 .

345. Id. at 454 .

346. Treaty on the Execution of Penal Sentences, U.S.-Mex., Nov. 25, 1976, 28 U.S.T. 7399.

The following year Congress passed the enabling legislation for the treaty, the Act of Oct. 28, 1977,

Pub. L. No. 95-144, 91 Stat. 1212 (codified as amended at 10 U.S.C. $\$ 955$ (2006); 18 U.S.C. $\$ \$ 3244,4100-15(2006))$.

347. Transhir ol: OFhinderst to OR from Forligin COUntries, H.R. REp. No. 95-720, at *29.

348. Id. at $* 26$. 
begs an important question whose answer depends on a variety of factors such as how long the prisoner has been in the country, how deep his ties are to it, and so forth. If, for example, a criminal who entered the United States only a month before committing a deportable crime is imprisoned in his home country (say, Mexico), this is not imprisonment in a "foreign" jail. In addition, it is not obvious why prisoners who may be transferred out of state without their consent should have a greater legal right to object to transfers back to their country of nationality.

Second, Congress may also have believed that consent was necessary to insulate the treaty from subsequent and potentially recurring legal attack, and thus provided for the consent verification proceedings. However, as detailed in Appendix 5, the relevant history strongly suggests that neither the Constitution nor international law requires prisoner consent before a transfer may be made, although some human rights commentators advocate such consent. In contrast, transfer to a prison that violates U.S. constitutional standards, however, would likely violate the Eighth Amendment.

Indeed, in 1996, Congress included a provision in the immigration reform statute urging the President to renegotiate the PTTs-especially that with Mexico-to eliminate the prisoner consent requirement, assure incarceration in the transferee country for the duration of the prisoner's American sentence, and subsidize the foreign prison system in order to prevent any Eighth Amendment violation. ${ }^{349}$ Notwithstanding the strong demand for reform of these twelve bilateral and two multilateral PTTs, Appendix 5 indicates that almost nothing has changed, relatively few prisoners have sought transfers, and few transfers have in fact occurred-only 155 from federal prisons in 2009 and 247 in $2010 .^{350}$ This dismaying non-implementation of the PTTs is due to a combination of factors: the consent requirement and legal obstacles created by the treaty provisions, diplomatic opposition by treaty partners, especially Mexico and their refusal to repatriate many of their citizens who committed crimes in the United States, and bureaucratic lassitude, ignorance, and lack of incentives on the part of DOJ and State Department officials. ${ }^{351}$

\section{Immigrant Criminals' Ties to the United States}

As noted in the Introduction, many commentators point out that deportation of immigrants, including criminals, can have very harsh consequences for the immigrant, his family, and their community in the United States. These consequences are so severe that such deportation, especially for

349. For details, see Appendix 5.

350. U.S. Dep't of Justice, Office of Enforcement Operations, Prisoner Transfer: JanuaryDECEMBER 2010, (2011), available at http://www.justice.gov/criminal/oeo/docs/Statistics.pdf.

351. See Schuck \& Williams, supra note 30. 
long-term residents with only the most tenuous ties to the country of origin, should require additional legal safeguards. ${ }^{352}$ Along with many other commentators, I have long advocated more protection for deportable immigrants, ${ }^{353}$ and indeed the Supreme Court has recently provided this protection in cases in which an immigrant's guilty plea may result in his deportation. ${ }^{354}$ In many ways, the 1996 immigration law has exacerbated this problem. $^{355}$

Those concerns, however, must be balanced against the important, competing social interests in reducing prison overcrowding and the other high costs of incarceration, as well as reducing the risks of recidivism both by citizens and non-removable immigrant prisoners who are released prematurely because of the prison-overcrowding crisis. Officials who are guided and constrained by legal standards that appropriately take these competing interests into account can best balance these interests. In Part V, I discuss what these standards should be and the process for applying them.

\section{E. Competition for Limited Enforcement Resources}

Law enforcement resources are limited and enforcement priorities other than the early deportation of criminals compete for these scarce resources. To the extent that earlier deportations would impose additional costs-that is, costs above and beyond the status quo such as deportations effectuated only after the sentence is served (estimated in Appendix 6) - such additional costs must be considered in the overall decision-making assessment of the proposal presented in Part V. But it is hard to see why the proposal's decision process would impose any marginal costs at all. After all, under the imprisonment-before-deportation rule, ICE officials will have to engage in a roughly similar decision-making process in order to determine when, how, and where ${ }^{356}$ to deport the immigrant criminal. Under that rule, the deportation decision will simply be made later rather than earlier.

\section{F. Political Factors}

The politics surrounding efforts to reduce prison overcrowding and prison costs are fierce. Taxpayers want relief from prison costs, but they also fear more crime if criminals are released prematurely, which presumably explains

352. See sources cited supra note 35.

353. Peter H. Schuck, The Transformation of Immigration Law, 84 ColuM. L. Rev. 1, 24-27, 66-68 (1984).

354. See Padilla v. Kentucky, 559 U.S. 356 (2010).

355. Peter H. Schuck, Citizens, Strangers, and In-Betweens: Essays on Immigration and Citizenship 143-45 (1998). See also Padilla, 559 U.S. at 363-64 (noting that the 1996 law increased the deportation risks of immigrant criminals).

356. The INA already constrains the determination of where the criminal will be deported. 8 U.S.C. $\$ 1231$. 
why California officials have had so little success in early release. ${ }^{357}$ At the same time, localities where prisons provide scarce government jobs, prison suppliers, prison guard unions, and others with a strong stake in large prison populations oppose reductions. Resolving these conflicts is exceedingly difficult, as ex-Governor Schwarzenegger discovered in California and Governor Andrew Cuomo is discovering in New York. ${ }^{358}$ The prospect of removing criminal immigrants before they serve their sentences may also provoke objections that the scheme is unfair to U.S. citizen criminals, who are not eligible for such early release-although under the proposal described in the next Part, the removed criminals would serve their full sentences in their countries of origin.

\section{Toward a Policy of Earlier Deportation}

In some circumstances, sound immigration enforcement policy would counsel in favor of having an immigrant criminal serve his entire sentence before being deported. For example, it might take the entire sentence for the United States to arrange for a criminal's actual deportation to the country of origin. As noted in Part IV, the government might doubt a country's ability or willingness to keep a criminal imprisoned for his full term upon return, and it might fear that if he is released in that country prematurely (or is not imprisoned at all), he would re-enter the United States illegally. The U.S. Government might also want to keep him in our prisons so that he can be questioned about criminal activity by him or by others. Family ties, medical needs, or other humanitarian reasons might also justify keeping him here, albeit under lock and key. Therefore, there are many other situations in which the government might conclude that deportation would be ill-advised.

Conversely, there are many other situations, probably a significant majority, in which American society would, on balance, be well-served by deporting immigrant criminals as soon as is practicable once their convictions and deportation orders became final, and in which any moral claims by the criminal to remain are less than compelling. Common examples of such immigrant criminals include those guilty of violent crimes, ${ }^{359}$ those who likely pose a high risk of recidivism, those who have only recently arrived in the United States, those who are eager to be deported, ${ }^{360}$ and those without strong family ties here.

357. Supra at Part I.d.

358. See Muradyan supra note 116, at 484-85 (regarding allocation of resources for California's prison). See also Thomas Kaplan, Cuomo Administration Is Closing 7 Prisons, 2 in New York City, N.Y. Times (July 1, 2011) A.16 (regarding allocation of resources for New York's prisons).

359. Interestingly, the two statutory exceptions to the existing imprisonment-before-deportation rule both require the opposite-that the crime be a "nonviolent offense." INA $\$ 241$ (a)(4)(B).

360. See, e.g., Letter from Julio Cesar Borrell, an inmate in Elmira Correctional Facility, to author (Dec. 27, 2010) (on file with author), in which Borrell desperately seeks deportation to the Dominican Republic, where his family and friends live. 
Yet even in such common situations, the imprisonment-before-deportation rule prohibits the authorities from acting-unless a statutory " $\mathrm{B}$ " exception applies $^{361}$ —and even then, as Appendix 3 details, officials seldom use these exceptions. The PTT regime in its present form is more of an obstacle to early deportation than a meaningful resource for effectuating it.

\section{A. Changing the Imprisonment-Before-Deportation Rule}

Congress should repeal the traditional imprisonment-before-deportation rule, replacing it with one of two options. The first option is to repeal the current imprisonment-before-deportation rule altogether, leaving the government free to decide whether, when, and where to deport him. Under existing law, the government already exercises discretion about whether or not to deport those individuals, including criminals, whom the immigration statute makes deportable; this would not change. However, for those criminals whom the government does decide to deport, the government would have broader discretion about when to initiate deportation, including the possibility (now virtually a requirement) of doing so only after the criminal has served his sentence. As a second option, Congress could adopt a rule with the opposite default: early deportation, including the possibility of deporting the criminal before the completion of his sentence in the United States-or even before any incarceration has occurred. As a default rule, it would not be mandatory. Thus, the government could still decide to imprison for the full term before deportation.

What legal standards would guide and constrain these officials' choices? Under either approach, the law should articulate the important individual and community values that the officials must seek to protect and balance. ${ }^{362}$ Individual values should include: maintaining the integrity of families in the United States, especially those with children or spouses who are U.S. citizens; the length of time the immigrant has spent in the United States; his desire, or lack thereof, for deportation; and other humanitarian factors such as acute needs for medical treatment. Community values should include: the seriousness of the offense, with violence and harm to the U.S. community weighing heavily in favor of early deportation; ${ }^{363}$ the risk of recidivism; the degree of prison overcrowding in his jurisdiction; the length of time remaining in his sentence, which would affect the U.S. incarceration costs to be avoided; the receiving country's willingness and ability to ensure that he

361. 8 U.S.C. \$1231(a)(4)(B) (2012).

362. Note that some of these values will-or at least should-have already been considered when ICE sought, and the immigration court issued, the final deportation order.

363. Because this factor is integral to the decision to seek early deportation, this criterion deserves special attention. Many commentators seeking to distinguish "serious" from "non-serious" offenses focus on drug-related crimes, yet even this distinction is difficult to apply. Appendix 7 discusses this point. For some crimes such as terrorism, of course, deportation might actually increase the risk of harm to American society. 
completes his sentence there; the likelihood of his re-entering the U.S. illegally after the receiving country releases him; and legitimate diplomatic considerations. The weight to be accorded to each of these criteria could be specified in the new legislation or left instead to official discretion. It is possible, then, that early deportation would be advisable under the criteria even if the receiving country's willingness to incarcerate him for the rest of his term is doubtful, or if some possibility of his re-entering legally exists. These contingencies are certainly weighty factors militating against early deportation, but would not necessarily be dispositive on the question of timing. ${ }^{364}$

Using these criteria, it is hard to predict how much new fact-finding and analysis would be required for officials to make the decision to deport or not deport, and if to deport, when to do so. The law should require the decision maker to provide the immigrant criminal with a proposed written statement of reasons under these criteria, and should provide the criminal an opportunity to challenge those reasons in writing before a final decision on early deportation is made. Because of the need to apply and integrate multiple criteria, however, that final decision based on this record would necessarily involve the exercise of substantial administrative discretion.

How extensive should the process surrounding this decision be? Although specifically answering this question requires details of the proposed system, at least four reasons suggest that the administrative and judicial process for deciding when to deport such criminal immigrants should be quite limited. First, he will already have had the right to contest his deportation before the immigration court and in an Article III court, including review of any claims that he might have asserted for discretionary relief and for withholding of removal to a particular state. ${ }^{365}$ Second, he will already have exercised the right to challenge his criminal conviction and sentence both at the trial level and, if he wishes, on appeal; some of the factors relevant to the length of his sentence will already have been brought to bear. Third, under existing law, once he has exhausted any appeal of his final deportation order, ${ }^{366}$ the government's decision to deport an individual-and more to the point here, when to do so-is entirely discretionary (assuming that it qualifies for one of

364. In February 2013, to cope with looming budget cuts, the DHS released certain undocumented immigrants held in immigration detention across the country. The agency's priority for detention, according to a spokesperson, was "serious criminal offenders and other individuals who pose a significant threat to public safety." See Alicia A. Caldwell, DHS Releasing Illegal Immigrants Before the Sequester, Associated Press, February 26, 2013.

365. Another procedural possibility for his deportation, although apparently seldom employed, is judicial removal. 8 U.S.C. $\$ 1228$.

366. In practice, years may pass between the time that the jury convicts and the time when the defendant exhausts his appeal of that conviction, and most prisoners begin serving time once they are sentenced; release pending appeal is uncommon. Email from James B. Jacobs, Professor, New York University School of Law, to author (Feb. 21, 2011) (on file with author). 
the Section 241(a)(4) exceptions). ${ }^{367}$ Accordingly, the proposal, by creating an additional right to a statement of reasons for an early deportation decision and to an opportunity to controvert those reasons, would go well beyond what the law now requires. Indeed, the proposal might be criticized for going too far beyond the existing procedure, considering that in an enforcement system whose credibility, efficacy, fairness, and deterrence value have long been severely undermined by existing delays in implementing deportation orders, any additional delays could exacerbate the system's already notorious dysfunctionality. For this reason, the proposal seeks to minimize this additional process, consistent with basic fairness to the criminal immigrant.

To be sure, the prospect of being removed against one's will to a prison abroad with harsher conditions, and perhaps away from one's family, might impact a constitutionally protected interest. This would require more process than the proposal provides for the deportation timing decision, especially if such process would improve the decision maker's information and reduce errors. But the marginal benefits of such additional process must be demonstrated rather than being assumed, and those putative benefits must then be compared with the substantial costs of further delays. Proponents of additional process bear a heavy burden of proof.

\section{B. Renovating the PTT Regime}

In addition to changing the current imprisonment-before-deportation rule, Congress and the President should renovate the PTT system whose enormous deficiencies were discussed in Part IV.C and detailed in Appendix 5. Congress, by statute, has already encouraged the President to negotiate new PTTs to replace the existing ones, using diplomacy and financial incentives to persuade the treaty partner to accept repatriation even without the prisoner's consent, and ensure that (1) the deported prisoner will actually serve the remainder of his U.S.-imposed term there, and (2) the conditions of imprisonment there meet the minimum health, safety, and other standards applicable to prisoners in the United States. Congress has already authorized the federal government to negotiate with the receiving countries for the right to build, manage, and fund such prisons in those countries. ${ }^{368}$

Such diplomacy, which must proceed on a country-by-country basis, would be very challenging. The incentives shaping the transferee country's negotiating position would be complex. Nevertheless, the first-cut analyses in Appendices 6 and 8 suggest that such a program would be immensely cost-effective for the United States and could be made attractive to the transferee country as well, depending on the value of the per-prisoner

367. I assume here that the government's decision is not infected by discrimination based on a legally protected characteristic such as race. Otherwise, the decision would likely be illegal.

368. If that country is not a suitable place for repatriation, the existing legal criteria for selecting another receiving country can be used. 8 C.F.R. $\$ 241.4(b)$. 
subsidies and other benefits that the United States would transfer to the receiving country.

Even if such a program proved infeasible, however, the proposal discussed above for replacing the traditional imprisonment-before-deportation rule with an administrative process to rationalize and support early deportation should be far superior to the status quo for those cases in which transfers pursuant to a PTT can indeed be effectuated. The criteria for deciding whether or not to deport the prisoner early would enable the government to consider the social and legal risks of doing so-primarily the risks that the transferee state would not incarcerate him for the prescribed period or under humane conditions, that the deporting officials would be subject to tort liability for unconstitutional conditions in the foreign prison, ${ }^{369}$ and that he would re-enter the United States illegally after release by that state. In those events, the United States might still deport him early if the criteria militated in favor of such a decision.

\section{CONCLUSION}

Overcrowded prisons constitute a very serious social problem of many dimensions: human rights threats; violence against prisoners and guards; breakdown of order and discipline; obstacles to prisoner rehabilitation and good health; fiscal integrity; and violation of constitutional or statutory rights. Despite immense and growing pressures to reduce prison populations, so far California, other states, and the federal government have been unable to do so without creating what the responsible officials believe are undue risks to public safety. ${ }^{370} \mathrm{~A}$ variety of policy changes have been proposed, some are being tried, and some of these may prove to be partly successful. Even so, the problem remains, and in some states it may be getting worse.

The evidence cited in this article demonstrates that early deportation of immigrant criminals would confer immense benefits on federal and state taxpayers, and on the remaining prisoners, at little or no marginal costs. To garner these fiscal advantages, however, the federal and state governments will have to work hard to dismantle the legal, political, bureaucratic, and diplomatic obstacles that have prevented early deportations. Although these governments have not mustered the will to do so in the past, the situation may be changing dramatically. The extraordinary fiscal, and thus political and legal pressures that these governments face is suddenly making plausibleeven urgent-what was previously unthinkable. ${ }^{371}$ The relative attractive-

369. See Bivens v. Six Unknown Named Agents of Federal Bureau of Narcotics, 403 U.S. 388, 389 (1971) (recognizing cause of action against individual officials violating constitutional rights).

370. See supra notes 160-161 and accompanying text.

371. Gary Fields \& Nathan Koppel, States Seek Prison Breaks, WAl.L. St. J., Feb. 8, 2011, at A3 (noting hard-pressed states adopting long-resisted reforms). Apparently, even law-and-order conservatives now support reforms designed to reduce corrections costs, reforms that were previously 
ness of the early deportation proposal presented here compared with the huge political costs of the alternatives - cutting firmly-embedded entitlements, shrinking other popular public programs, and releasing large numbers of potentially dangerous criminals before officials deem it safe to do so-may fundamentally alter the incentives and calculus of federal and state politicians, making this proposal more palatable politically. In hard times when difficult tradeoffs must be made, stranger things have happened. But even if the proposal's goals were not to be fully achieved, continuing the status quo would be increasingly unacceptable. In the face of highly dysfunctional systems like overcrowded prisons and immigration enforcement, those assessing even imperfect proposals must always ask the "compared to what?" question. ${ }^{372}$

supported primarily by liberals. See generally, The Conservative Case for Reform, RiGHTonCrimE. CoM, http://rightoncrime.com (last visited Feb. 9, 2014).

372. See, e.g., Peter H. Schuck, Refugee Burden-Sharing: A Modest Proposal, 22 YAlE J. INT'LL. 243, 250 (1997). 
